NBER WORKING PAPER SERIES

\title{
GOING SOFT: HOW THE RISE OF SOFTWARE BASED INNOVATION LED TO THE DECLINE OF JAPAN'S IT INDUSTRY AND THE RESURGENCE OF SILICON VALLEY
}

\author{
Ashish Arora \\ Lee G. Branstetter \\ Matej Drev \\ Working Paper 16156 \\ http://www.nber.org/papers/w16156 \\ NATIONAL BUREAU OF ECONOMIC RESEARCH \\ 1050 Massachusetts Avenue \\ Cambridge, MA 02138 \\ July 2010
}

This research was supported by the Software Industry Center at Carnegie Mellon University and benefitted from the research assistance of Ms. Kanako Hotta of UCSD. We acknowledge with gratitude useful comments from Hiroyuki Chuma, Anthony D'Costa, Kyoji Fukao, Shane Greenstein, Susumu Hayashi, Takao Kato, Toshiaki Kurokawa, Mark Kryder, Koji Nomura, Jeffrey Smith, David Weinstein and participants in the 2009 Spring Meeting of the NBER Productivity Program, the 2009 NBER Japan Project Conference, and the September 2009 Meeting of the Japan Economic Seminar at Columbia University. The views expressed herein are those of the authors and do not necessarily reflect the views of the National Bureau of Economic Research.

NBER working papers are circulated for discussion and comment purposes. They have not been peerreviewed or been subject to the review by the NBER Board of Directors that accompanies official NBER publications.

(C) 2010 by Ashish Arora, Lee G. Branstetter, and Matej Drev. All rights reserved. Short sections of text, not to exceed two paragraphs, may be quoted without explicit permission provided that full credit, including $(\odot$ notice, is given to the source. 
Going Soft: How the Rise of Software Based Innovation Led to the Decline of Japan's IT Industry and the Resurgence of Silicon Valley

Ashish Arora, Lee G. Branstetter, and Matej Drev

NBER Working Paper No. 16156

July 2010

JEL No. O31,O32,O33

\begin{abstract}
This paper documents a shift in the nature of innovation in the information technology (IT) industry. Using comprehensive data on all IT patents granted by the USPTO from 1980-2002, we find strong evidence of a change in IT innovation that is systematic, substantial, and increasingly dependent on software. This change in the nature of IT innovation has had differential effects on the performance of the IT industries in the United States and Japan. Using a broad unbalanced panel of US and Japanese publicly listed IT firms in the period 1983-1999, we show that (a) Japanese IT innovation relies less on software advances than US IT innovation, (b) the innovation performance of Japanese IT firms is increasingly lagging behind that of their US counterparts, particularly in IT sectors that are more software intensive, and (c) that US IT firms are increasingly outperforming their Japanese counterparts, particularly in more software intensive sectors. The findings of this paper thus provide a fresh explanation for the relative decline of the Japanese IT industry in the 1990s. Finally, we provide suggestive evidence consistent with the hypothesis that human resource constraints played a role in preventing Japanese firms from adapting to the shift in the nature of innovation in IT.
\end{abstract}

Ashish Arora

Fuqua School of Business

Duke University

Box 90120

Durham, NC 27708-0120

and NBER

ashish.arora@duke.edu

Lee G. Branstetter

Heinz College, School of Public Policy

and Management

and Department of Social and Decision Sciences

Carnegie Mellon University

2504B Hamburg Hall

Pittsburgh, PA 15213

and NBER

branstet@andrew.cmu.edu
Matej Drev

Heinz College, School of Public Policy

and Management

Carnegie Mellon University

242 Hamburg Hall

Pittsburgh, PA 15213

mdrev@andrew.cmu.edu 


\section{Introduction}

The surge of innovation in Information Technology (IT) is one of the great economic developments of the last two decades. This period also coincides with the unexpected resurgence of the United States IT sector, belying the gloomy predictions about the US IT industry popular in the late 1980s and early 1990s (e.g. Cantwell, 1992; Arrison and Harris, 1992). In this paper, we argue that these two developments are closely related.

We present evidence that a change has occurred in the nature of the innovation process in IT. Starting in the late 1980s and accelerating in the 1990s, technological change in IT has taken on a trajectory that is increasingly software intensive. We show that non-software IT patents are significantly more likely to cite software patents, even after controlling for the increase in the pool of citable software patents. We also show that employment of software professionals has increased in IT industries. While these shifts are broad-based, we also see substantial differences across IT sub-sectors in the degree to which they taken place. We exploit these differences to sharpen our empirical analysis in the manner described below.

If the innovation process in IT has indeed become more dependent on software competencies and skills, then firms better able to use software advances in their innovation process will benefit more than others. Indeed, we argue that the shift in software intensity of IT innovation has differentially benefited American firms over their Japanese counterparts. Our

results from a sizable unbalanced panel of the largest publicly traded IT firms in US and Japan for the period 1983-1999 show that US IT firms have started to outperform their Japanese 
counterparts, both as measured by productivity of their innovative activities, and as measured by their stock market performance. ${ }^{1}$

The timing and the concentration of this improvement in relative performance appears to be systematically related to the software intensity of IT innovation. We show that the relative strength of American firms tends to grow in the years after the rise in software intensity had become well established. Furthermore, the relative improvement of the U.S. firms is greatest in the IT sub-sectors in which the measured software intensity of innovation is the highest. Finally, we present evidence suggesting that much of the measured difference in financial performance disappears when we separately control for the software intensity of IT innovation at the firm level.

This paper is structured as follows. Section II documents the existence of a shift in the technological trajectory of IT, Section III empirically explores its implications for innovation performance of US and Japanese IT firms, and Section IV discusses the possible explanations for the trends we observe in our data. We conclude in Section V with a summary of the key results and suggestions for future work.

\section{The Changing Technology of Technological Change in IT}

A survey of the computer and software engineering literature points to an evident increase in the role of software for successful innovation and product development in various parts of the IT industry. The share of software costs in product design has increased steadily over time (Allan et al, 2002) and software engineers have become more important as high-level

\footnotetext{
1 These results parallel the findings of Jorgenson and Nomura (2007), who demonstrate that Japanese TFP rose rapidly for decades, converging to U.S. levels, but then began diverging from it around 1995. Their industry level analysis suggests that a change in the relative performance of the IT-producing industries (which we study in this paper) and the IT-using industries were particularly important in driving the shift from convergence to divergence. Jorgenson and Nomura do not attempt to explain the mechanisms behind relative declines in productivity.
} 
decision-makers at the system design level in telecommunications, semiconductors, hardware, and specialized industrial machinery (Graff, Lormans, and Toetenel, 2003). Graff, Lormans, and Toetenel (2003) further argue that software will increase in importance and complexity in a wide range of products, such as mobile telephones, DVD players, cars, airplanes, and medical systems. Industry observers claim that software development and integration of software applications has become a key differentiating factor in the mobile phone and PDA industry (Express Computer, 2002). A venture capital report by Burnham (2007) forcefully argues that that the central value proposition in the computer business has shifted from hardware to systems and application software.

Similarly, De Micheli and Gupta (1997) assert that hardware design is increasingly similar to software design, so that the design of hardware products requires extensive software expertise. Gore (1998) argues that peripherals are marked by the increasing emphasis on the software component of the solution, bringing together hardware and software into an integrated environment. ${ }^{2}$ Kojima and Kojima (2007) suggest that Japanese hardware manufacturers will face increasing challenges due to the rising importance of embedded software in IT hardware products. In sum, there is broad agreement among engineering practitioners and technologists about the increasing role of software in various parts of IT. In the next section, we validate this assertion formally, using data on citation patterns of IT patents.

\footnotetext{
2 Personal discussions with Mark Kryder, former CTO of Seagate, confirmed that software has become an increasingly important driver of product functionality and product differentiation in the hard disk drive industry.
} 


\section{Measuring the Shift in the Technology of Technological Change in IT}

\section{Approach}

If innovation in IT truly has come to rely more heavily on the use of software, then this reality should be reflected in citations of patent documents. We should observe that more recent cohorts of IT patents cite software technologies with increasing intensity, and this should be the case even when we control for the changes over time in the volume of IT and software patenting. We therefore use citations by non-software IT patents to software patents as a measure of the software intensity of IT innovation.

Patents have been used as a measure of innovation in mainstream economic research at least since the early 1960s. The possible uses of patent citations in economic research have been well documented (Jaffe and Trajtenberg, 2002), and although problems in using citations to measure knowledge flows have been identified, they are still extremely useful in the context of our research project.

Following Caballero and Jaffe (1993) and Jaffe and Trajtenberg (1996, 2002), we use a citation function model in which we model the probability that a particular patent, $\mathrm{p}$, applied for in year $\mathrm{t}$, will cite a particular patent, $\mathrm{P}$, granted in year $\mathrm{T}$. This probability is determined by the combination of an exponential process by which knowledge diffuses and a second exponential process by which knowledge becomes superseded by subsequent research (Jaffe and Trajtenberg, 2002). The probability, $\operatorname{Pr}(\mathrm{p}, \mathrm{P})$, is a function of the attributes of the citing patent $\mathrm{p}$, the attributes of the cited patent $\mathrm{P}$, and the time lag between them (t-T), as depicted formally below:

$$
\operatorname{Pr}(p, P)=\alpha(p, P) \cdot \exp \left(-\beta_{1}(t-T) \cdot\left(1-\exp \left(-\beta_{2}(t-T)\right)\right.\right.
$$

We sort all potentially citing patents and all potentially cited patents into cells corresponding to the attributes of patents. The attributes of the citing patents include the citing 
patent's grant year, its geographic location, and its technological field (IT, software). The attributes of the cited patents are the cited patent's grant year, its geographic location, and its technological field. Thus, the expected value of the number of citations from a particular group of citing patents to a particular group of cited patents can be expressed as the following:

$$
E\left(c_{a b c d e f}\right)=n_{a b c} \cdot n_{d e f} \cdot \alpha_{a b c d e f} \cdot \exp \left(-\beta_{1}(t-T) \cdot\left(1-\exp \left(-\beta_{2}(t-T)\right)\right.\right.
$$

where the dependent variable measures the number of citations made by patents in the appropriate categories of grant year (a), geographic location (b), and technological field (c) to patents in the appropriate categories of grant year (d), geographic location (e), and technological field (f). The alpha terms are multiplicative effects estimated relative to a benchmark or "base" group of citing and cited patents. Rewriting equation (2) gives us the Jaffe - Trajtenberg (2002) version of the citation function:

$$
p\left(c_{a b c d e f}\right)=\frac{E\left(c_{a b c d e f}\right)}{n_{a b c} \cdot n_{d e f}}=\alpha_{a b c d e f} \cdot \exp \left(-\beta_{1}(t-T) \cdot\left(1-\exp \left(-\beta_{2}(t-T)\right)\right.\right.
$$

Adding an error term, we can estimate this equation using the nonlinear least squares estimator. The estimated equation thus becomes the following:

$$
p\left(c_{a b c d e f}\right)=\alpha_{a} \cdot \alpha_{b} \cdot \alpha_{c} \cdot \alpha_{d} \cdot \alpha_{e} \cdot \alpha_{f} \cdot \exp \left(-\beta_{1}(t-T) \cdot\left(1-\exp \left(-\beta_{2}(t-T)\right)+\varepsilon_{a b c d e f}\right.\right.
$$

In estimating equation (4) we adjust for heteroskedasticity by weighting the observations by the square root of the product of potentially cited patents and potentially citing patents corresponding to the cell, that is

$$
w=\sqrt{\left(n_{a b c}\right) \cdot\left(n_{d e f}\right)}
$$

\section{Data}

We use patents granted by the United States Patent and Trademark Office (USPTO) between 1980 and 2002. We use the geographic location of the first inventor to determine the 
"nationality" of the patent. We identified patents belonging to IT, broadly defined, by using a classification system based on USPTO classes, developed by Hall, Jaffe, and Trajtenberg (2001). They classified each patent into one of six broad technological categories: (1) chemical, (2) computers \& communications, (3) drugs \& medical, (4) electrical \& electronic, (5) mechanical, and (6) others. They further broke down each category, generating a total of 36 technological subcategories. We applied their system and identified IT patents broadly defined as those belonging to any of the following categories: computers \& communications, electrical devices, or semiconductor devices. We obtained these data from the updated NBER patent dataset. ${ }^{3}$

Next, we identified software related patents, which is a pressing challenge in itself. There have been three significant efforts to define a large set of software patents. Graham and Mowery (2003) defined software patents as an intersection of those falling within a narrow range of International Patent Classification (IPC) classes and those belonging to packaged software firms. This created a sample that omitted large numbers of software patents, according to Allison et al, (2006).

The second effort was that of Bessen and Hunt (2007), who defined a software invention as one in which the data processing algorithms are carried out by code either stored on a magnetic storage medium or embedded in chips. They rejected the use of official patent classification systems for defining the set of software patents, and used a keyword search method instead. They identified a small set of patents that adhered to their definition, and then used a machine learning algorithm to identify similar patents in the patent population, using a series of

\footnotetext{
${ }^{3}$ Downloaded from the following link: http://elsa.berkeley.edu/ bhhall/bhdata.html (12/15/2007)
} 
keywords in the patent title and abstract. Recently, Arora et al. (2007) used a similar approach that connects the Graham-Mowery and Bessen-Hunt definitions. ${ }^{4}$

We used a combination of broad keyword-based and patent class strategies to identify software patents. First, we generated a set of patents, applied for after January $1^{\text {st }} 1980$ and granted before December $31^{\text {st }} 2002$, that used the words "software" or "computer program" in the patent document. Then, we defined the population of software patents as the intersection of the set of patents the query returned and IT patents broadly defined as described above, granted in the period 1980-2002. This produced a dataset consisting of 104,407 patents.

These data are potentially affected by a number of biases. Not all invention is patented, and special issues are raised by changes in the patentability of software over the course of our sample period - this makes it all the more important for us to control for the expansion in the pool of software patents over time, as we do. We also rely on patents generated by a single authority - the USPTO - to measure invention for both U.S. and Japanese firms. However, Japanese firms have historically been among the most enthusiastic foreign users of the U.S. patent system. Evidence suggests that examination of the U.S. patents of Japanese firms provides the researcher with a reasonably accurate portrayal of their inventive activity (Branstetter, 2001; Nagaoka, 2007). This is particularly likely to be true in IT, given the importance of the U.S. market in the various components of the global IT industry.

\section{Results}

Figure 1 shows trends over time in the fraction of total (non-software) IT patents' citations that are going to software patents. While the trends for both Japanese and U.S. firms

\footnotetext{
${ }^{4}$ Allison et al. (2006) rejected the use of both the standard classification system and keyword searches, resorting to the identification of software patents by reading through them manually. Although potentially very accurate, this method is inherently subjective and not scalable.
} 
rise significantly over the $1990 \mathrm{~s}$, then level off a bit in the 2000s, the measured gap between Japanese and U.S. firms rises substantially over the period. A one-tailed t-test reveals that these differences are statistically significant at conventional levels for every year shown. However, this does not control for a variety of other factors, and we turn next to parametric analysis.

Figure 1: Software Intensity of Non-Software IT Patents (Measured by fraction of IT patent citations going to software patents)

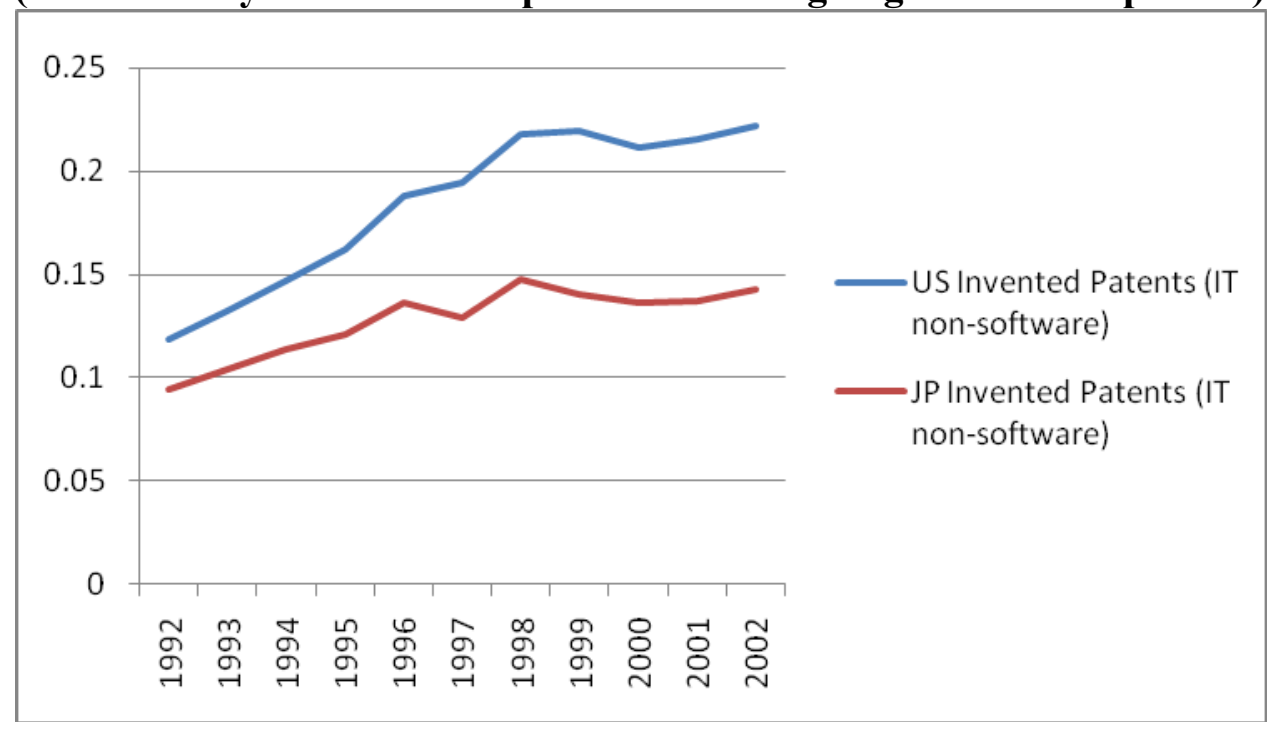

The unit of analysis in Table I is an ordered pair of citing and cited patent classes. In this regression, we are primarily interested in the coefficient on the software patent dummy. Our regression model is multiplicative, so a coefficient of 1 indicates no change relative to the base category. Our coefficients are reported as deviations from 1 . The software patent dummy is large, positive, statistically significant, and indicates that IT patents in the 1990s are 1.34 times more likely to cite software patents than prior IT patents, controlling for the sizes of available IT and software patent pools. The second specification in Table I includes only software patents in the population of possibly cited patents. The coefficients on the citing grant years show a sharp increase in citation probabilities from 1992 to 2002. An IT patent granted in 1996 is 1.74 times more likely to cite a software patent than an IT patent granted in 1992. Furthermore, an IT patent 
granted in 2002 is almost 4 times more likely to cite a software patent than that granted in 1992. Comparing this trend to that of the specification in the left-hand column of Table I, we see that this trend is much more pronounced, suggesting that software patents are becoming increasingly important for IT innovation broadly defined. In Table I, we also explore citation differences between Japanese and non-Japanese invented IT inventions. The specification in the left-hand column indicates that Japanese invented IT patents are 34 percent less likely to cite other IT patents than non-Japanese IT patents. However, they are 93 percent less likely to cite software patents than non-Japanese IT patents. This result is corroborated by the regression in the righthand column, where the coefficient on the Japanese dummy again shows that Japanese invented IT patents are significantly less likely to cite software patents than non-Japanese patents.

The citation function results were subjected to a number of robustness checks. Concerned that our results might be driven by large numbers of U.S.-invented software patents appearing in the more recent years of our sample, we estimated the propensity of U.S. IT patents to cite software patents generated outside the U.S. and found a rise in this propensity qualitatively similar to that depicted in Table 1 . We also directly controlled for the disproportionately high likelihood that patents cite patents from the same country, but our result that Japanese IT hardware patents are systematically less likely to cite software over time was robust to this. Finally, concerned that this result might be observed at least partially due to traditionally stronger university-industry ties in the United States ${ }^{5}$, we also estimated a version of the citations function in which we excluded all university-assigned patents and those citing them, and found our results to be robust to this as well.

\footnotetext{
${ }^{5}$ See Goto (2000) and Nagaoka (2007) for a more detailed discussion.
} 
The citations function's complexity makes it difficult to estimate different tendencies for Japanese and American firms to increase their propensity to cite software patents over time, holding all other factors constant, but we see evidence consistent with this in the raw data. The results from the two specifications in Table I suggest that software innovation is (increasingly) important for IT innovation, especially in the US. The U.S. Bureau of Labor Statistics data on U.S. employment by occupation and industry from $1999-2007^{6}$ reveal trends consistent with a rising importance of software in IT innovation. For instance, Figure 2 illustrates how two measures of the share of software engineers in total employment in the computer and peripheral equipment manufacturing industry have trended upward over time. We see similar trends in other IT subsectors as well. Interestingly, the relative share of software engineers in total employment across subsectors appears to accord with patent citation-based measures of software intensity. The share is highest in computers and peripherals, lowest in audio and visual equipment manufacturing, and at intermediate levels in semiconductors.

\footnotetext{
${ }^{6}$ Methodological changes in the survey make it difficult to track occupational employment in the U.S. IT industry in a consistent way over time, particularly in comparing the periods before and after 1999.
} 


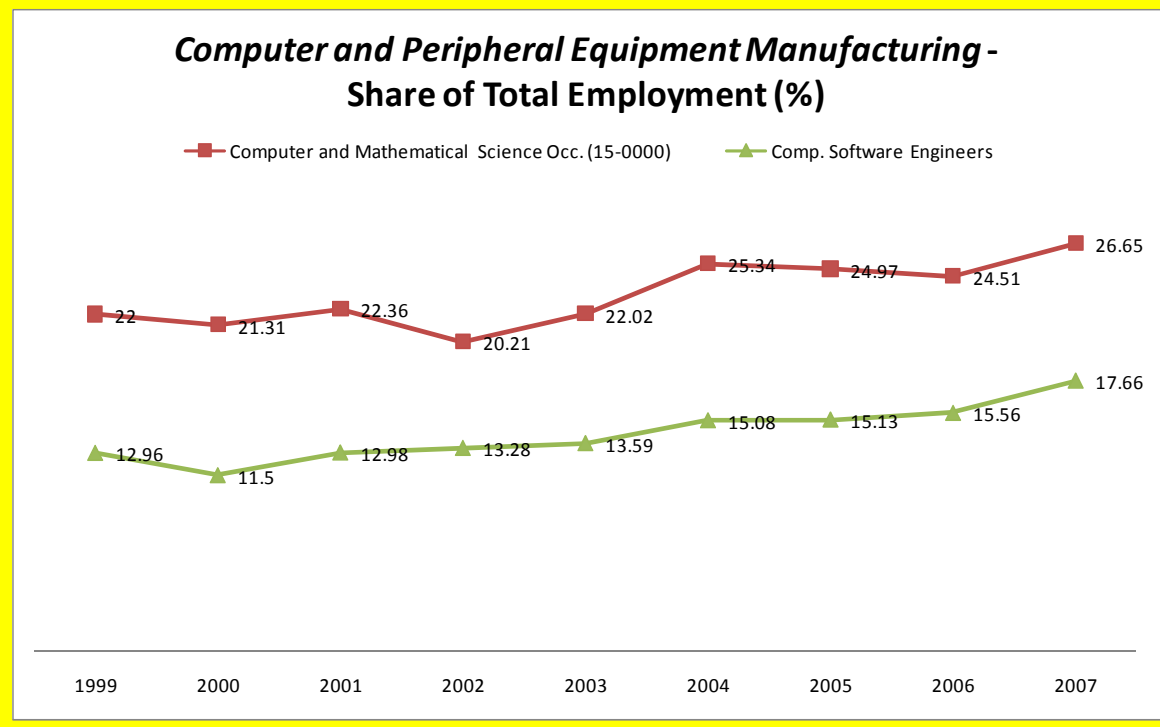

Source: Bureau of Labor Statistics, Occupational Employment Survey, 1999-2007

Note: Data include domestically employed H1-B visa holders

\section{Comparing US and Japanese Firm-Level Innovation Performance in IT}

Our citation function results suggest that there has been a shift in the nature of technical change within IT - invention has become much more software intensive. Our results also suggest that U.S. firms have more actively incorporated software into their inventive activity than have Japanese firms. If this is true, then it is reasonable to expect that changes in the relative performance of Japanese and American firms may be related to the software intensity of the industry segments in which they operate. In segments of IT where innovation has become most reliant on software, we should expect to see American firms improve their relative innovation performance relative to Japanese firms. In segments of IT where innovation does not draw heavily on software, we would expect less of an American resurgence. As we shall see, two very different measures of relative performance show exactly this pattern. 
We use two of the most commonly employed empirical approaches to compare firmlevel innovation performance of US and Japanese IT firms: the innovation (patent) production function and the market valuation of R\&D. While the former approach relates $R \& D$ investments to patent counts and allows us to study the patent productivity of R\&D, the second approach relates R\&D investment to the market value of the firm and explores the impact of R\&D on the value of the firm (Tobin's Q).

\section{Patent Production Function}

This approach builds on Pakes and Griliches (1984) and Hausman, Hall, and Griliches (1984). We use a log-log form of the patent production function.

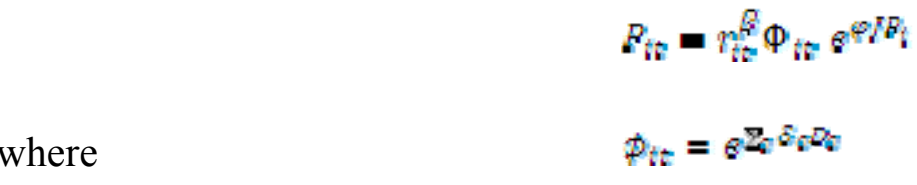

In equation (6), $\mathrm{P}_{\mathrm{it}}$ are patents taken out by firm $\mathrm{i}$ in period $\mathrm{t}, \mathrm{r}_{\mathrm{it}}$ are research and development expenditures, $\mathrm{JP}_{\mathrm{i}}$ indicates if the firm is Japanese, and $\Phi$ 's represent innovation-sector-specific technological opportunity and patenting propensity differences $\mathrm{D}$ across $\mathrm{c}$ different innovation sectors as specified in (7). Substituting (7) into (6), taking logs of both sides, and expressing the sample analog we obtain the following:

$$
p_{i s}=\beta p_{i s}+\sum_{\sigma} \dot{\theta}_{q} D_{q}+\varphi / R_{i}+w_{\text {is }}
$$

where $p_{i t}$ is the natural log of new patents (flow) and the error term which is defined below.

$$
\mu_{i t}=\xi_{i j}+u_{1 t}
$$

We allow the error term in (9) to contain a firm-specific component, $\xi_{\mathrm{i}}$, which accounts for the intra-industry firm-specific unobserved heterogeneity, and an iid random disturbance, $\mathrm{u}_{\mathrm{it}}$. The presence of the firm-specific error component suggests using random or fixed effect estimators. 
Since the fixed effects estimator precludes time-invariant regressors, including the firm origin indicator, we feature the pooled OLS and random effects estimators, and use the fixed effects estimator as a robustness check.

\section{Private Returns to R\&D and Tobin's Q}

Griliches (1981) pioneered the use of Tobin q regressions to measure the impact of R\&D on a firm's economic performance (see Hall (2000) for a detailed review). In this approach, efficient capital markets are assumed, so that the market value of the firm represents the value maximizing combination of its assets. We can represent the market value $\mathrm{V}$ of firm $\mathrm{i}$ at time $\mathrm{t}$ as a function of its assets:

$$
V_{i t}=f\left(A_{i t}, K_{i t}\right)
$$

where $A_{i t}$ is the replacement cost of the firm's tangible assets, typically measured by their book value, and $\mathrm{K}_{\mathrm{it}}$ is the replacement value of the firm's technological knowledge, typically measured by stocks of R\&D expenditures ${ }^{7}$. We follow the literature, which assumes that the different assets enter into the equation additively:

$$
\left.V_{i t}=q_{t} t_{i t}+\beta * K_{t t}\right)^{*}
$$

where $\mathrm{q}_{\mathrm{t}}$ is the average market valuation coefficient of the firm's total assets, $\beta$ is the shadow value of the firm's technological knowledge measuring the firm's private returns to $R \& D$, and $\sigma$ is a factor measuring returns to scale. Again following practice in the literature (e.g. Hall and Oriani, 2006), we assume constant returns to scale $(\sigma=1)$. Then, by taking natural logs on both sides of (11) and subtracting $\ln \mathrm{A}_{\mathrm{it}}$, we obtain the following expression that relates a firm's technological knowledge to its value above and beyond the replacement cost of its assets, Tobin's Q:

\footnotetext{
${ }^{7}$ The construction of variables is explained in greater detail in subsequent sections.
} 


$$
\ln Q_{i}=\ln \left(\frac{V_{i s}}{A_{i t}}\right)=\ln q_{t}+\ln \left(1+\beta_{s} *\left(\frac{K_{i s}}{A_{i s}}\right)\right)
$$

Following Hall and Kim (2000) and others, we estimate a version of (12) using the nonlinear least squares estimator, with time dummies and a firm origin indicator. We were unable to estimate a specification with firm-fixed effects because the NLS algorithms did not converge. As a robustness check, we estimated a linearized version of (12) with fixed effects.

\section{Data and Variables}

\section{Sample}

Our sample consists of large publicly traded IT companies in the United States and Japan, observed from 1983 to 1999. We obtained the sample of US firms from historical lists of constituents of Standard \& Poor's (S\&P) US 500 and S\&P 400 indices. The resulting set of firms was refined using Standard \& Poor's Global Industry Classification Standard (GICS) classification ${ }^{8}$ so that only firms appearing in "electronics", "semiconductors", "IT hardware" and "IT software and services" categories remained in the sample. This initial set of approximately 220 firms was narrowed further in the following way: (a) only firms that were granted at least 10 patents in the 1983-1999 period were retained, (b) US firms in "IT software and services" were removed to achieve compatibility, ${ }^{9}$ and (c) for Tobin's Q regressions only, firms for which at least 3 consecutive years of positive $R \& D$ investment and sales data were available were kept in the sample. This yielded an unbalanced panel of 140 and 135 US IT firms for patent production function and Tobin's Q regressions respectively.

\footnotetext{
${ }^{8}$ GICS, the Global Industry Classification System, is constructed and managed by Moody's in collaboration with Compustat.

${ }^{9}$ NTT is the only Japanese firms in "IT services and software" in our sample.
} 
The initial sample of 154 large publicly traded Japanese IT firms derived from the Development Bank of Japan (DBJ) database ${ }^{10}$ was supplemented by an additional 37 firms included in Standard \& Poor's Japan 500 index as of January $1^{\text {st }} 2003^{11}$ that belong to either "electronics", "semiconductors", "IT hardware", or "IT software and services"..

Japanese accounting standards do not force firms to report $R \& D$ data in a uniform way, and we were forced to obtain self-reported R\&D expenditure data for Japanese firms from annual volumes of the Kaisha Shiki $\mathrm{Ho}^{12}$ survey. Lack of reliable R\&D expenditure data for some firms led to their exclusion from our sample. We further restricted the sample by (a) dropping all firms without at least 10 patents in the observed period, (b) dropping Nippon Telephone and Telegraph, and, for Tobin's Q regressions, (c) all firms for which at least three consecutive years of R\&D investment and positive output data were not available in DBJ. This produced a final sample of 98 and 88 Japanese IT firms for the patent production function and Tobin's Q regressions respectively.

\section{Locating Firms in Software Intensity Space}

To explore how innovation performance differentials between US and Japanese firms vary with software intensity, we classify firms into industry segments. GICS provided us with a classification of all US firms in our sample into four sectors - "electronics", "semiconductors", "IT hardware", and "IT software and services". Japanese firms were classified manually using the two-digit GSIC classification data from the S\&P Japan 500 along with data from Japan's

\footnotetext{
${ }^{10}$ We thank the Columbia Business School Center on the Japanese Economy and Business for these data.

${ }^{11}$ January $1^{\text {st }}, 2003$ was the date of creation of this index.

${ }^{12}$ Kaisha Shiki Ho (Japan Company Handbooks) is an annual survey of Japanese firms, published by the Japanese equivalent of Dow Jones \& Company, Toyo Keizai Inc. We thank Ms. Kanako Hotta for assistance in obtaining these data from the collections at the School of International Relations and Pacific Studies of the University of California at San Diego.
} 
Standard Industrial Classification (JSIC), supplemented by data from Google Finance, Yahoo! Finance and corporate websites.

We construct two separate measures of software intensity, both of which suggest a similar ranking of IT subsectors. First, we use the shares of software patents in total patents taken out by the firms, averaged across firms in an industry category. Second, we calculate the fraction of citations to software parents by non-software IT patents, averaged across firms $\mathrm{n}$ a sample category. Table II presents summary statistics for both these measures of software intensity. As expected, electronics is the least software intensive, followed by semiconductors and IT hardware. A two-sided test for the equality of means rejects that the intensities are the same in any pair of sectors when we use the share of software patents as our measure. The second measure, citations to software patents, yields similar results, albeit at lower levels of significance in some cases. Tables III and III-2 calculate the industry averages of our measures of software intensity separately for U.S. and Japanese firms. In general, the ranking of industries in terms of software intensity suggested by the overall sample appears to apply to the countryspecific subsamples. ${ }^{13}$ Japanese firms are disproportionately located in less software intensive sectors, and within those sectors, are less software intensive. ${ }^{14}$

Taking the assignment of firms to the different IT industries as given ${ }^{15}$, we test whether US firms outperform Japanese firms, and whether this performance gap is more marked in IT industries that are more software intensive.

\footnotetext{
${ }^{13}$ Depending on the measure, statistical tests of equality are not always significant at the conventional threshold levels when we disaggregate by country of origin, and when Japanese software intensity is measured by citations to software in non-software patents, electronics is (insignificantly) more software intensive than semiconductors.

${ }^{14}$ This is true in five out of six cases, although the measured differences are not always statistically significant.

${ }^{15} \mathrm{We}$ address the issue of the validity of making this assumption in subsequent sections of this paper, and find that our main results are robust to using variation in firm-level software intensity assignments instead of industry classifications.
} 


\section{Construction of Variables}

Patent Counts: Patent data for our sample of firms were collected from the updated NBER patent dataset containing patents granted by the end of 2002. Compustat firm identifiers were matched with assignee codes based on the original and updated matching as constructed and available on Bronwyn Hall's website. ${ }^{16}$ The matching algorithm was manually updated by matching strings of Compustat firm names and strings of assignee names as reported by the USPTO. An identical procedure was used for matching Japanese firms to their patents, except that we based it on a Tokyo Stock Exchange (TSE) code - assignee code matching algorithm previously used in Branstetter (2001).

$R \& D$ Investment: Annual R\&D expenditure data for US firms were collected from Compustat, and a set of self-reported R\&D expenditure data for Japanese firms were collected from annual volumes of the Kaisha Shiki Ho survey. We deflated R\&D expenditures following Griliches (1984), and constructed a separate R\&D deflator for US and Japanese firms that weighs the output price deflator for nonfinancial corporations at 0.51 and the unit compensation index for the same sector at 0.49 . Using data on wage price indexes for service-providing and goods-producing employees, ${ }^{17}$ we constructed a single unit compensation index for each country, and then applied the proposed weights and appropriate producer price indexes to compute the R\&D deflators and deflate the $R \& D$ expenditure flows.

\footnotetext{
${ }^{16}$ Downloaded from the following link: http://elsa.berkeley.edu/ bhhall/bhdata.html (12/15/2007)

${ }^{17}$ We obtained these data from the Bureau of Labor Statistics and Statistics Bureau of Japan, respectively.
} 
$R \& D$ stocks: We calculated R\&D capital stocks from R\&D expenditure flows using the perpetual inventory method, with a $15 \%$ depreciation rate. ${ }^{18}$ We used 5 pre-sample years of R\&D expenditures to calculate the initial stocks. ${ }^{19}$

Market Value of the Firm: Market value of a firm equals the sum of market value of its equity and market value of its debt (Perfect and Wiles, 1994). Market value of equity equals the sum of the value of outstanding common stock and the value of outstanding preferred stock. The value of outstanding common (preferred) stock equals the number of outstanding common (preferred) shares multiplied by their price. For US firms, we used year-close prices, year-close outstanding share numbers, and year-close liquidating values of preferred capital. For Japanese firms, the only available share price data were year-low and year-high prices, and we used the arithmetic mean of the two to obtain share price for each firm-year combination. In addition, preferred capital data was not available for Japanese firms. Although this can introduce a source of measurement error in our dependent variable, as long as preferred capital does not systematically vary with time and across technology sectors in a particular way, our results regarding sector and sector-origin differences will remain valid. For market value of debt we used total long-term debt and debt due in one year. For Japanese firms, we used fixed liabilities as a proxy for the value of long-term debt and short-term borrowings as a proxy for the value of short-term debt. ${ }^{20}$

\footnotetext{
${ }^{18}$ See Griliches and Mairesse (1984) and Hall (1990) for a detailed description and discussion of this methodology. We used several depreciation rates between $10 \%$ and $30 \%$, with little change in the results.

${ }^{19}$ When the expenditure data was not available, we used first 5 years of available R\&D expenditure data, "backcast them" using linear extrapolation, and calculated the initial R\&D capital stock based on the projected R\&D expenditures.

${ }^{20}$ Perfect and Wiles (1994) suggests that the measurement error in using book value of debt is modest.
} 
Replacement Cost of Assets: The replacement cost of the firm's assets is the deflated year-end book values of total assets. ${ }^{21}$ where the deflator is a country-specific capital goods deflator obtained from the Bureau of Labor Statistics and the Statistics Bureau of Japan, respectively.

\section{Patent Production Function Results}

Figure 3 compares the number of patents per firm for the US and Japanese firms in our sample. We observe that Japanese firms obtain more non-software IT patents than their US counterparts. Between 1983 and 1988, the average number of non-software IT patent applications were almost identical for Japanese and US firms. Between 1988 and 1993, patent applications by Japanese firms outpaced those of US firms, after which both grew at the same pace. By contrast, Japanese firms file fewer and increasingly fewer software patents than their US counterparts. The difference has grown steadily since the late 1980s and at an increasing pace in the mid and late 1990s.

21 Perfect and Wiles (1994) note that different calculation methodologies do result in different absolute replacement cost values, but do not seem to bias coefficients on R\&D capital. In a discussion particular to calculating replacement cost of assets in Japan, found in Hoshi et al. (1991), several complex methodologies were proposed. For the purpose of this paper, we did not compare our results against the alternative of using replacement cost calculated with their methodology. 
Figure 3: Average Number of non-software IT and Software Patents Per Firm

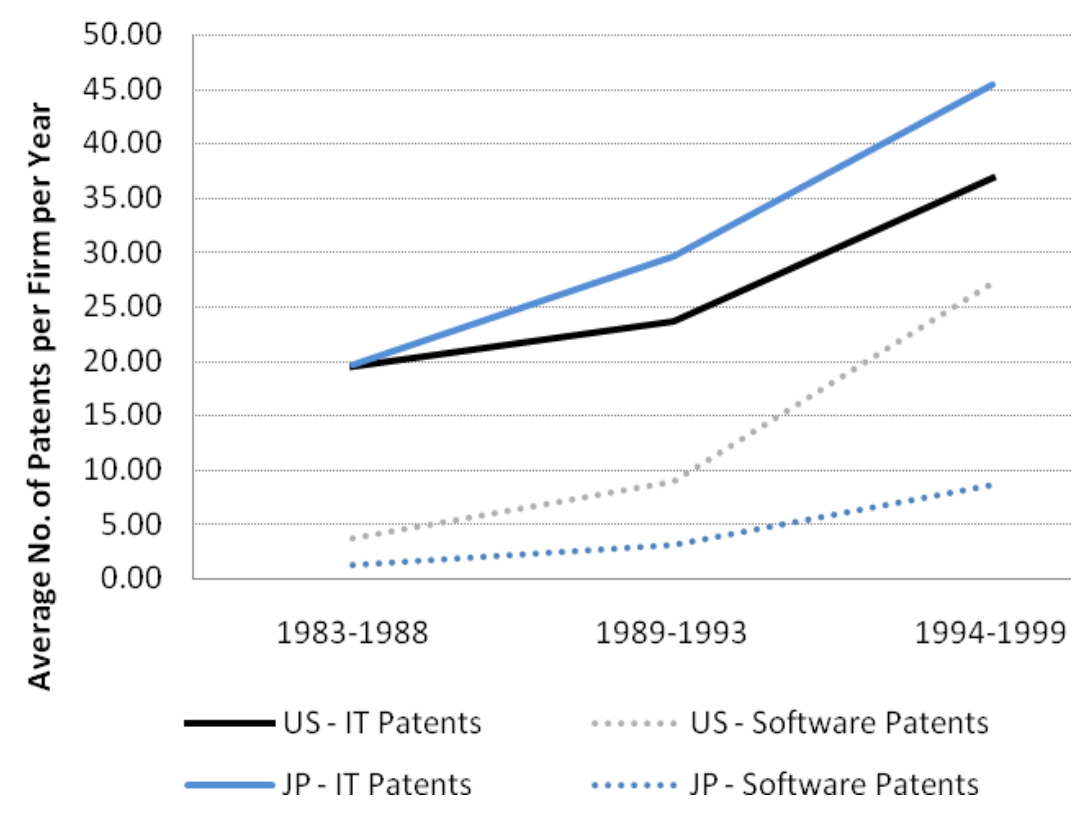

Table $\mathrm{V}$ in Appendix A reports the estimates of the patent production functions of Japanese and US IT firms. Our first key result is presented in Figure 4 below, which plots the pooled OLS average difference in log patent production per dollar of R\&D, between Japanese and US firms in our sample through time, controlling for time and sector dummies. We see that R\&D spending by Japanese firms was $40 \%$ more productive than in their US counterparts during 1983-1988, but 30\% less productive during 1989-1993. This trend accelerated in the 1990s, resulting in Japanese IT firms producing $60 \%$ fewer patents, controlling for the level of R\&D spending, than their US counterparts in the period 1994-1999. 
Figure 4: Average Japan-US Productivity Differences, Entire Sample

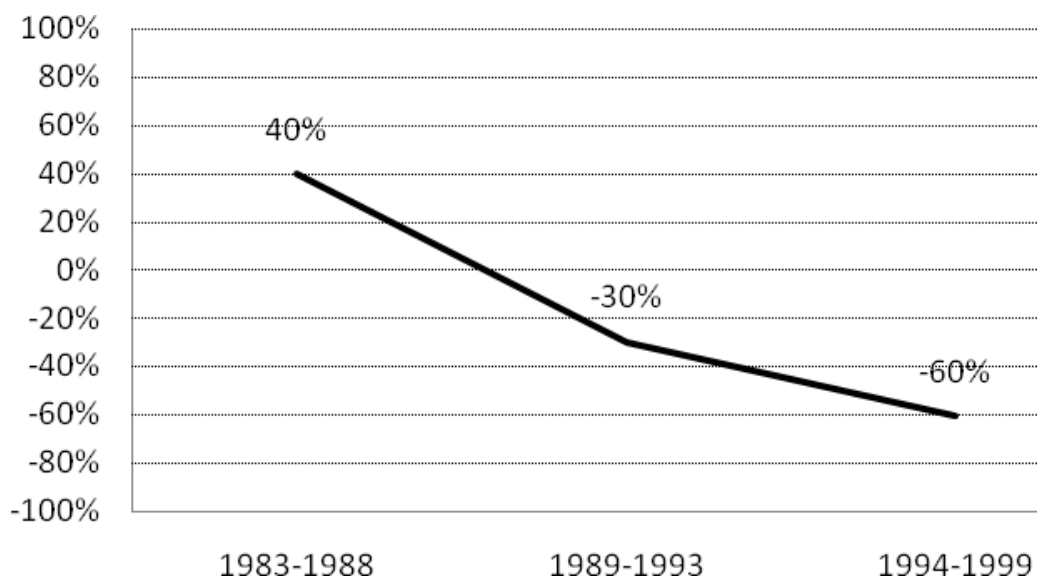

Based on results from Table V. Appendix A. Reported are pooled OLS estimation coefficients.

Figure 5: Average Japan-US Productivity Differences, By Software Intensity Sector

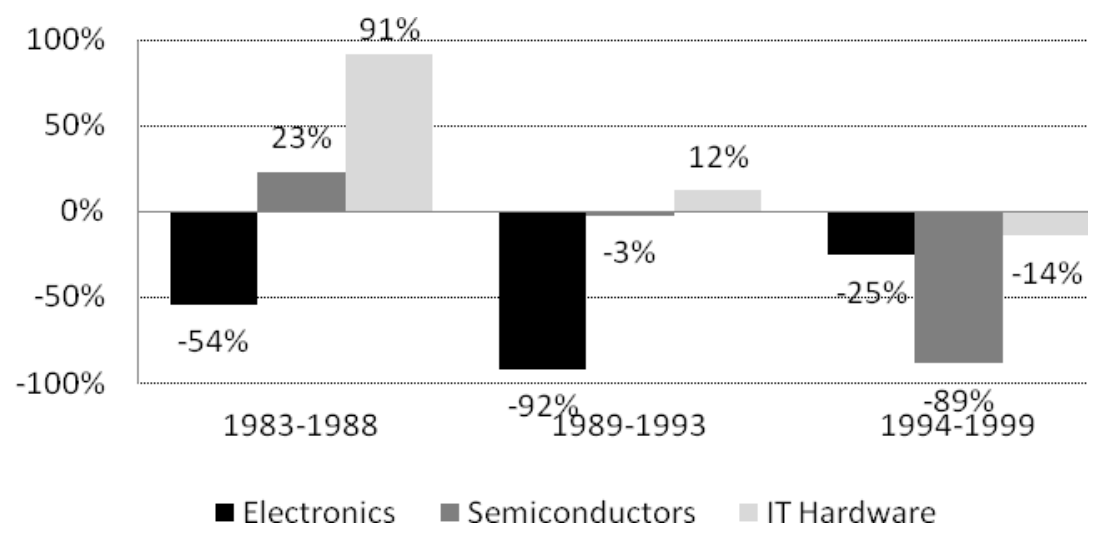

Based on results from Table V. of the Appendix. Reported are selected pooled OLS estimation coefficients.

Figure 5 reports Japan-U.S. differences in average R\&D productivity by IT sector, where the measure of $R \& D$ productivity is based on patent output controlling for $R \& D$ input. In electronics, previously shown to be the least software intensive, and where average software intensity is similar between US and Japanese firms, Japanese firms have been less productive in patent production in the 1980s and early 1990s, but have been catching up to their US 
counterparts in the mid and end 1990s. ${ }^{22}$ On the other hand, in semiconductors and IT hardware, which have significantly higher software intensity than electronics, and where average software intensity of US firms is greater than of Japanese firms, Japanese firms exhibited higher productivity in the mid 1980s, lost all of their advantage by the turn of the 1990s, and increasingly started to lag behind their US counterparts in the mid to end 1990s.

All of the results are statistically significant at the $5 \%$ level and robust to changes in the particularities of estimation techniques. Random effects and fixed effects estimators, which take into account firm-specific unobserved differences in patent productivity, do not produce qualitatively different results, suggesting that our results are not driven by unobserved firmspecific research productivity or patent propensity differences. The dependent variable in these estimations is the $\log$ of total patents applied for by firm $i$ in year $t$. We estimated our regressions using the log of IT patents, and the log of IT patents excluding software patents, with no qualitative change in the results. We also weighted total patent output by subsequent citations and by the number of claims appearing in the patent documents, with no qualitative change in the results. $^{23}$

\section{Accounting for Alternative Hypotheses}

We find empirical results consistent with our view that a shift in the nature of technological change in IT has led to sharp changes in the relative performance of Japanese and U.S. IT firms. Our inference is strengthened when we consider these results alongside alternative explanations for the change in relative performance.

22 In the mid-2000s, Japanese electronics firms received a boost from the rapidly growing sale of so-called digital appliances, such as DVD recorders, digital cameras, and LCD televisions. Industry observers, such as Ikeda (2003), warned of imminent commoditization of these new products - a prediction that has been born out in the latter years of the decade.

${ }^{23}$ While we do not report these results in the paper, they are available by request. 
The collapse of the Japanese bubble economy at the end of the 1980s. The shift in relative performance is broadly coincident with the slowdown in the Japanese domestic economy that followed the collapse of Japan's "bubble economy" at the end of the 1980s. This domestic slowdown could have led to lower levels of R\&D expenditure by Japanese firms. ${ }^{24}$ However, a simple recession induced decline in R\&D investment cannot explain our results. We are estimating the productivity of R\&D in producing patents, rather than the number of patents produced. If Japanese firms sought cost savings (by eliminating marginal projects), then a decline in $R \& D$ expenditure should have resulted in higher not lower measured productivity. Budget pressures could have also led Japanese firms to change their patent propensity, filing fewer but higher quality patents outside Japan. However, estimates using citation weighted patents yield results similar to those reported above. More fundamentally, no simple story about a post-bubble slowdown in the domestic economy can explain the observed pattern, wherein the relative decline in productivity is greater in more software intensive segments.

Strong venture capital in America, weak venture capital in Japan. Kortum and Lerner (2001) provide evidence of the strong role played by venture capital backed firms in the acceleration of innovation in the United States in the 1990s. Recent Japanese scholarship (Hamada, 1996, Goto, 2000, Goto and Odagiri, 2003) stresses the relative weakness of venture capital in Japan as an impediment to the growth of science-based industries. However, we do not believe that our results are driven by these institutional differences. The IPO of Netscape is often viewed as the start of the venture capital boom in the U.S. IT sector. We delete from our database all U.S. firms that went public after the Netscape IPO, and obtain results qualitatively similar to those reported above. While it is certainly true that new firms adept at software-based

${ }^{24}$ One hastens to add, though, that these firms have always relied on export markets for a large fraction of their total revenues. 
innovation entered the market in the mid-to-late 1990s, often with backing from venture capitalists, our results do not depend on their inclusion in the sample. ${ }^{25}$.

Strong university-industry linkages in the U.S., weak linkages in Japan. Extensive evidence highlights the important links between industrial innovation and academic science in the U.S. Technologies initially developed in (and patented by) universities have led to important innovations in the U.S. Goto (2000), Nagaoka (2007), and many others have suggested that weaker Japanese universities and weaker formal mechanisms for university-industry technology transfer may have become increasingly important impediments to growth in Japan's sciencebased industries. We acknowledge the importance of these linkages. However, if universitygenerated inventions were an important element in the transformation of the U.S. IT sector, then corporate patents citing these university-generated inventions should be especially important in generating our empirical results. We delete all university-owned inventions and all corporate patents citing university-owned inventions from our data; the results do not change.

Technology standards and market dominance. Tanaka (2003) and other Japanese scholars have suggested that the increasing dominance of U.S. IT firms in the 1990s and beyond is driven largely by U.S. ownership of key technology standards in the industry. Once these standards are established, network externalities reinforce them, conferring upon the standard owners an almost unbeatable advance. We acknowledge that ownership of a major technology standard can be financially beneficial, but this is not driving our result. We can delete from our sample all U.S;. firms that could plausibly be described as owners of a major IT technology standard; this does

25 Of course, many U.S. IT firms active in the 1980s and early 1990s were backed at birth by venture capitalists. But this backing did not prevent the U.S. IT industry from losing ground to Japan in that era. Any argument linking the shift in relative performance of the two industries in the mid-to-late 1990s to venture capital would have to assert that new firms brought into the market in the mid-to-late 1990s were responsible for the shift; this is clearly not the case. 
not alter our results. The most (in)famous standard owner, Microsoft, is never included in the sample on which our estimates are based. We do not attempt to compare the research productivity of US and Japanese firms in the packaged software industry, because there are very few publicly traded Japanese firms in that segment. ${ }^{26}$ If we include the packaged software industry, the measured productivity differences would be even more favorable to the US. ${ }^{27}$

\section{Results Based on Private Returns to R\&D}

We begin by plotting the average difference in Tobin's Q between our sample of US and Japanese firms through time, shown in Figure 6 below. We observe that Japanese firms, on average, have had higher Q values than US firms in the mid 1980s, particularly in what would become more software intensive sectors - semiconductors and IT hardware. These differences diminished with the bursting of the Japanese economic bubble at the dawn of the 1990s, and Japanese Q values have lagged throughout the 1990s, especially in semiconductors, and to a lesser extent, also in IT hardware. Thus trends in average Tobin's Q values by sector parallel those in patent production.

Moving beyond the descriptive analysis, we regress Tobin's $\mathrm{Q}$ on the ratio of R\&D stocks by total assets to estimate private returns to R\&D (shadow value of R\&D). Table IV reports estimates of equation (12) by period using nonlinear least squares. It shows that the shadow price of $\mathrm{R} \& \mathrm{D} /$ Assets for US firms was negative and statistically significant in the period 1983-1988, but rose to positive and statistically significant levels by the mid to end 1990s. On

\footnotetext{
26 This means that U.S. software powerhouse firms such as Oracle, and Google are all omitted from the data set and play no role in our results.

${ }^{27}$ Towards the end of the 1990s, a small number of publicly listed firms, such as Softbank, that we could classify as software firms appeared on the Tokyo Stock Exchange. The Japanese videogame industry includes a handful of software-intensive game developers, but they are sufficiently different from their U.S. counterparts to make a comparison problematic. Motohashi (2009) uses a different data set to explore productivity trends in the Japanese software industry, but does not attempt an international comparison.
} 
the other hand, the coefficient on $\mathrm{R} \& \mathrm{D} /$ Assets for Japanese firms has not followed this trend. It has hovered just above 0 in the 1980s and dropped to just below 0 in the mid 1990s. In none of the periods was it statistically significantly different from 0 . This is consistent with what we observed when plotting the values of Tobin's Q through time, except that we see that it is not the Japanese who experienced a drop in returns, but that it is the US firms who exhibited a hike in private returns to $R \& D$.

Interestingly, this "reversal of fortune" for the market valuation of U.S. firm R\&D appears to be sensitive to the inclusion of a direct measure of software intensity. Table IV-2 reports the results of a regression in which we add the software intensity (measured by average firm citations to software in non-software IT patents), and also interact with R\&D/Assets. This additional regressor changes our results. The R\&D/Assets coefficient for U.S. firms is positive in the last period, but not statistically significant from zero. These results support the view that the relative increase in U.S. performance is related to software intensity.

Figure 6: Average Difference in Tobin's Q, By Sector

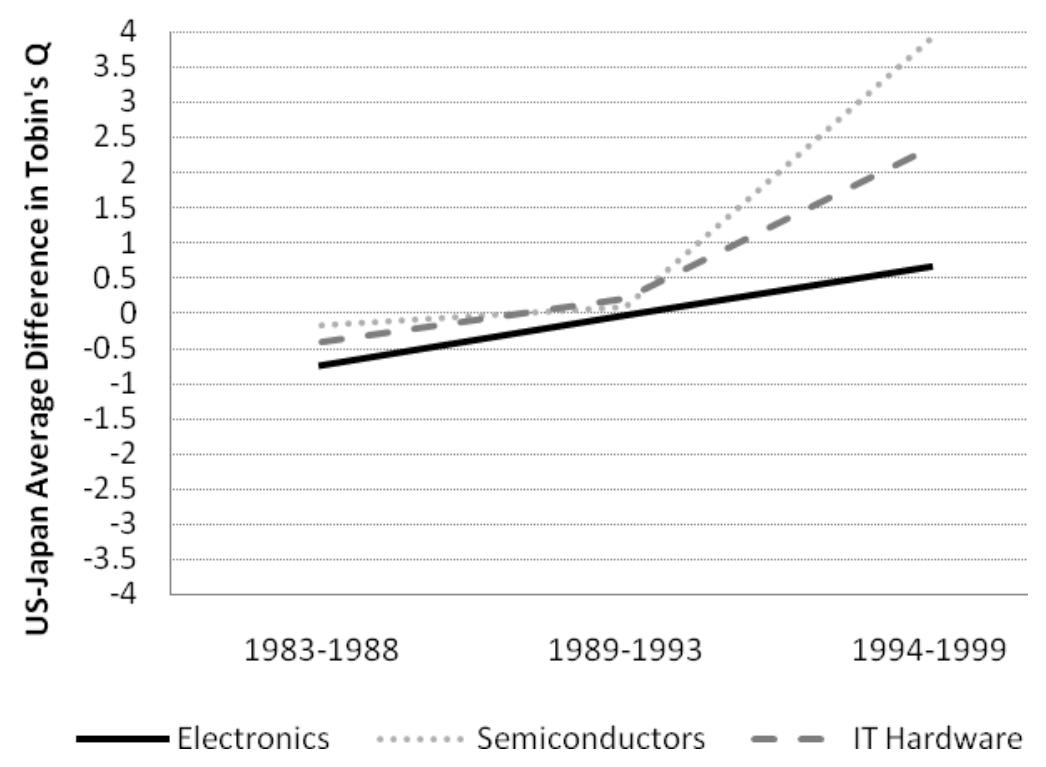

Tobin's Q as calculated in the database, averaged across sector. Calculated as JP average subtracted from US average. 
Figure 7 compares private returns to R\&D for Japanese and US firms by IT sector. As with patent productivity, we find that results differ by sector. In electronics, the least software intensive sector, the US firms started off with an advantage in the mid 1980s, before losing it all by the mid to end 1990s. The reverse is true in IT hardware, the most software-intensive sector. We report detailed regression results in Tables VII-IX of Appendix A.

\section{Figure 7: Average Difference in Private Returns to R\&D, By Sector}

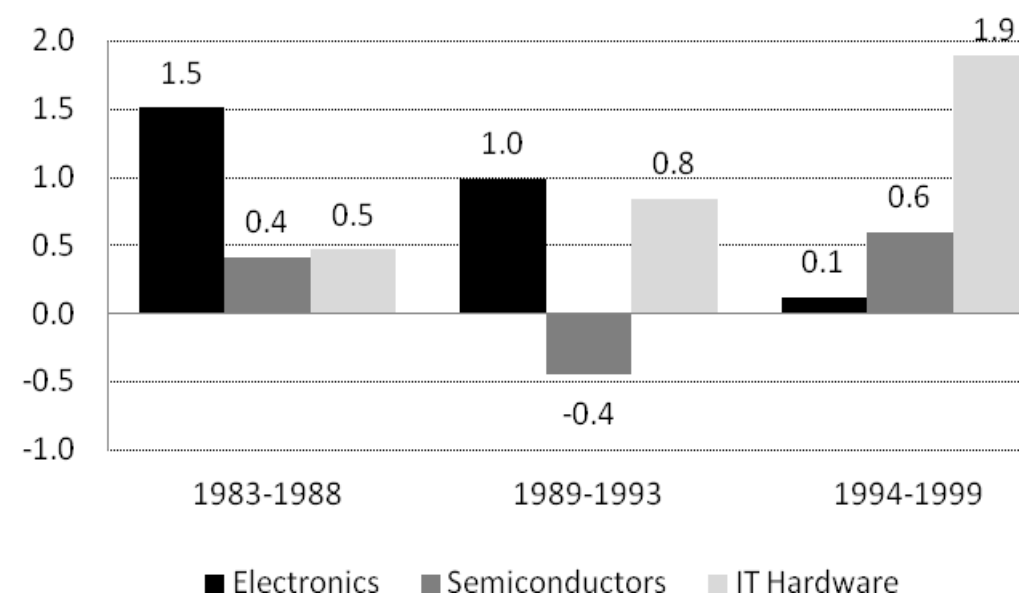

Shadow values of R\&D as estimated by NLS by sector. Calculated as JP average subtracted from US average.

We conducted several robustness checks. We first estimated versions of (12) using NLS and FE estimators, where we directly estimated time trends for private returns to R\&D separately for US and Japanese firms. Table VI shows that the direction of the trends remains unperturbed, but they lose their statistical significance when we use the NLS estimator on the sample of US firms. Private returns to R\&D for Japanese firms linger, as before, around 0, and have no significant trend over time. In the left columns of Tables VII-IX, we report estimates of the linear approximation using firm fixed effects. Again, we observe that the signs of the coefficients remain essentially unchanged, except in the case of US semiconductors, where the FE reveals a highly statistically significant positive trend in private returns to R\&D. 
As in the previous section, we consider our results alongside alternative explanations for the resurgence of the U.S. industry in the global marketplace. In order to address concerns about the possible effect of cross-country venture capital differences on our results, we also estimated versions of (12) by excluding VC-backed entrants from our sample, and found little qualitative change in our results. Similarly, in order to address the concern that our estimates might have been influenced by a few standard-setting US firms dominating the more software intensive industries, we re-estimated our regressions by excluding firms who owned major technological standards during the sample period, and again found little change in our results. ${ }^{28}$

In order to directly test the robustness of our results to changes in industry group assignment of firms, we estimated a linearized version of the regression where we assigned firms in our sample into groups of the same sizes as those suggested by the industry classification, but based on both firm-level shares of software patents and firm-level shares of citations directed towards software patents. We found our results to be qualitatively robust to this exercise that allowed us to estimate the regressions without imposing possibly restrictive assumptions about firm industry assignments. Finally, we estimated a version where we split US and Japanese firms into quartiles according to the firm-level share of software patents in total patents. We observe that US firms' private returns to R\&D increase with software intensity, while they fall in the case of Japanese firms. This is consistent with our results from above. However, when we perform the same exercise by sector, we observe that, in semiconductors and IT hardware this no longer holds, suggesting that our results might be driven by trends in electronics. This is plausible since Japanese firms are disproportionally located in this sector. Interestingly, we also observe that US firm's private returns to $R \& D$ increase with the software intensity of the sector when they are

\footnotetext{
${ }^{28}$ While we do not report these results in the paper, they are available upon request.
} 
also in the top quartile of software intensity. The same is true for Japanese firms. Conversely, private returns to $R \& D$ decrease with the software intensity of the sector for firms located in the bottom quartile of software intensity.

\section{Discussion}

The empirical part of our paper documents three key observations. First, we show that IT innovation has become more software intensive. Second, Japanese firms produce significantly fewer software inventions and rely less on software knowledge in innovation production than their US counterparts. Third, the innovation performance of Japanese IT firms is increasingly lagging behind, particularly in software intensive sectors. These differences remain even after we attempt to account for alternative explanations advanced in the literature for the relative decline of the Japanese industry. All this suggests, but does not conclusively demonstrate, a causal link running from the changing technology of technical change in IT to an inability of Japanese firms to respond adequately to the shift, leading to worsening performance.

What prevented Japanese firms from using software advances as effectively as U.S. firms? There are at least two explanations. The first is a resource constraint argument: softwareintensive IT innovation necessarily requires access to large numbers of software engineers at various skill levels. U.S.-based firms have access to a much larger specialized labor pool than do their Japanese counterparts. Japanese firms are not able - or, at least, have not yet been able -- to completely overcome their national labor resource constraints by offshoring their softwareintensive $R \& D$. The second explanation is one rooted in the failure of Japanese managers to understand and adequately respond to the changing nature of technological change in IT. 
Japan's relative weakness in many kinds of software has been widely recognized in the literature. ${ }^{29}$ Finan and Williams (1992) point to Japan's lack of an adequate pipeline for software engineers. Cusumano (1991) showed how Japan's electronics and hardware companies took special steps to increase the productivity of their scarce software labor. Other studies, citing reasons as diverse as the structure of the Japanese language and weak university-level computer science education programs, all pointed to the relatively weak software competence of many Japanese firms, the relatively weak software skills of many Japanese software workers, and the inadequate supply of highly skilled software labor in Japan (e.g., Fransman, 1995; Japanese Ministry of Internal Affairs and Communications, 2005; Kurokawa and Hayashi (2008)).

There are clusters of Japanese firms that have maintained their strong international market positions in software-intensive segments of IT. The most conspicuous example is probably the Japanese videogame sector. ${ }^{30}$ However, videogames sales are driven by artistic factors as well as purely technological ones, and Japanese developers have a rich local cultural tradition of manga (a Japanese art form akin to comic books in the West) and anime (animated films) to draw upon. The ability of a handful of firms to pursue a narrowly focused but softwareintensive innovation strategy would not seem to contradict the general picture of software weakness.

The level of local human capital would not be a constraint if knowledge flowed freely across countries. Unfortunately, it is widely acknowledged that tapping into foreign knowledge pools can be difficult (Jaffe, Trajtenberg, and Henderson 1993). Belderbos (2001) and Odagiri

\footnotetext{
${ }^{29}$ Anchordoguy (2000) and Tanaka (2003) have described in detail the relative weaknesses of the Japanese software industry in systems and applications software. Kojima and Kojima (2007) discuss weakness in embedded systems software.

${ }^{30}$ Japanese firms also maintain a strong position in robotics, one that they have held for years. The Japanese mobile phone service industry has been characterized by a high degree of software-intensive innovation, but these Japanese innovations have had little impact to date outside of the Japanese home market.
} 
and Yasuda (1997) document the relatively limited extent of Japanese R\&D activity outside Japan during the period under consideration. Belderbos, Fukao and Kwon (2006) conclude that Japanese foreign $R \& D$ spending was a relatively small fraction of total R\&D spending during the years of our sample period. Branstetter (2006) finds that the impact of Japanese R\&D subsidiaries in the U.S. on the research productivity of Japanese firms at home was positive but small. Anchordoguy (2000) provides circumstantial evidence that tapping into foreign software knowledge pools might be particularly difficult for Japanese firms due to language barriers, labor market frictions, and institutional factors. ${ }^{31}$ Japan's relatively restrictive immigration laws and its long history as an ethnically homogenous society mitigate against large-scale importation of skilled labor from foreign countries, creating barriers to bringing the foreign expertise (or experts) to Japan. All of these considerations suggest significant barriers to the ability of Japanese firms to move abroad to tap foreign knowledge or expertise. ${ }^{32}$

What if local labor resources really do matter? ${ }^{33}$ The available data make it difficult to precisely quantify the differences in software human resources between the U.S. and Japan, but the gap between the two is clearly large. Figure 8 presents data from a number of sources comparing the flows of new (potential) domestic IT workers during the latter years of our sample period. The U.S. National Science Foundation's SESTAT survey, conducted every two years, tracks science and engineering graduates across fields and disciplines from U.S. universities at

31 An important strand of literature in international economics argues that country-specific factor endowments are crucial for explaining comparative differences in innovation performance of industries in national economies. For instance Acemoglu (2002), Dudley and Moenius (2007) and others, argue that not only do countries specialize in the production of goods intensive in factors they are abundant in, but that they also specialize in innovation activities intensive in factors they are abundant with, a phenomenon they dub "factor-biased technical change".

32 Kojima and Kojima (2007) examine the available data on Japanese offshoring of software development to other countries. While the data are highly problematic, they suggest a very low level of offshoring relative to the U.S. something as low as $5-10 \%$ of the U.S. level - even by the mid-2000s.

33 Kerr and Lincoln (2008) examine the impact of fluctuations in H-1B immigrants on innovation at the city level; Hunt and Gauthier-Loiselle (2008) examine the impact of immigration more generally on innovation at the state level. We conjecture here that this impact has been highly concentrated in software intensive innovations. 
the bachelors and masters level. The annual Survey of Earned Doctorates tracks graduates at the doctoral level across disciplines and years. ${ }^{34}$ The Japanese Ministry of Education, Sports, and Welfare's Basic School Survey tracks graduates across disciplines at the bachelors, masters, and doctoral levels for Japanese universities, albeit with a slightly different breakdown of fields and disciplines. ${ }^{35}$ To make the figures as comparable as possible, we aggregate over IT software and hardware related disciplines to produce a count of total IT bachelors, masters, and Ph.D. level graduates for both countries. Using data from the U.S. Citizenship and Immigration Service and the Department of State on H-1B visa applications, approvals, and issuances, we create estimates of the number of temporary workers joining the U.S. labor force in "computer-related fields" under the auspices of an $\mathrm{H}-1 \mathrm{~B}$ visa. ${ }^{36}$ It is difficult to estimate with precision how many foreigners have been admitted to work as software or computer engineers in Japan. ${ }^{37}$ In Figure 8 , we assume that half of all foreigners newly admitted as "researchers," "engineers," or "intracompany transferees" are employed as IT workers - a far larger fraction than plausibly holds true in reality. Even this generous presumption fails to have much impact on the total estimated Japanese IT workforce.

\footnotetext{
34 These data can be downloaded from the NSF website; SESTAT data can be obtained from http://www.nsf.gov/statistics/recentgrads/ and SED data from http://www.nsf.gov/statistics/doctorates/, 35 We thank Professor Kyoji Fukao of Hitotsubashi University's Institute for Economic Research for valuable assistance in obtaining access to various editions of the Basic School Survey, and we also thank Professor Takao Kato of Colgate University and Professor Anthony D'Costa of Copenhagen Business School for helping us identify the Japanese data sources used in this paper.

36 Our data are drawn from reports by Lowell (2000) and Kirkegaard (2005).

${ }^{37}$ Japanese statistics track newly registered foreign workers across a number of broad categories including "researchers," "engineers," and "intracompany transferees." These data are reported annually in the Shutsu Nyukoku Kanri Toukei Nenpo (Annual Report of Statistics on Legal Migrants), published by the Japanese Ministry of Justice. We thank Professor Kyoji Fukao of Hitotsubashi University for help in getting access to these data.
} 
Figure8 ICT Human Resources, U.S. vs. Japan

(ICT graduates and H1-B immigrants into computer related-professions, 1995-2001)

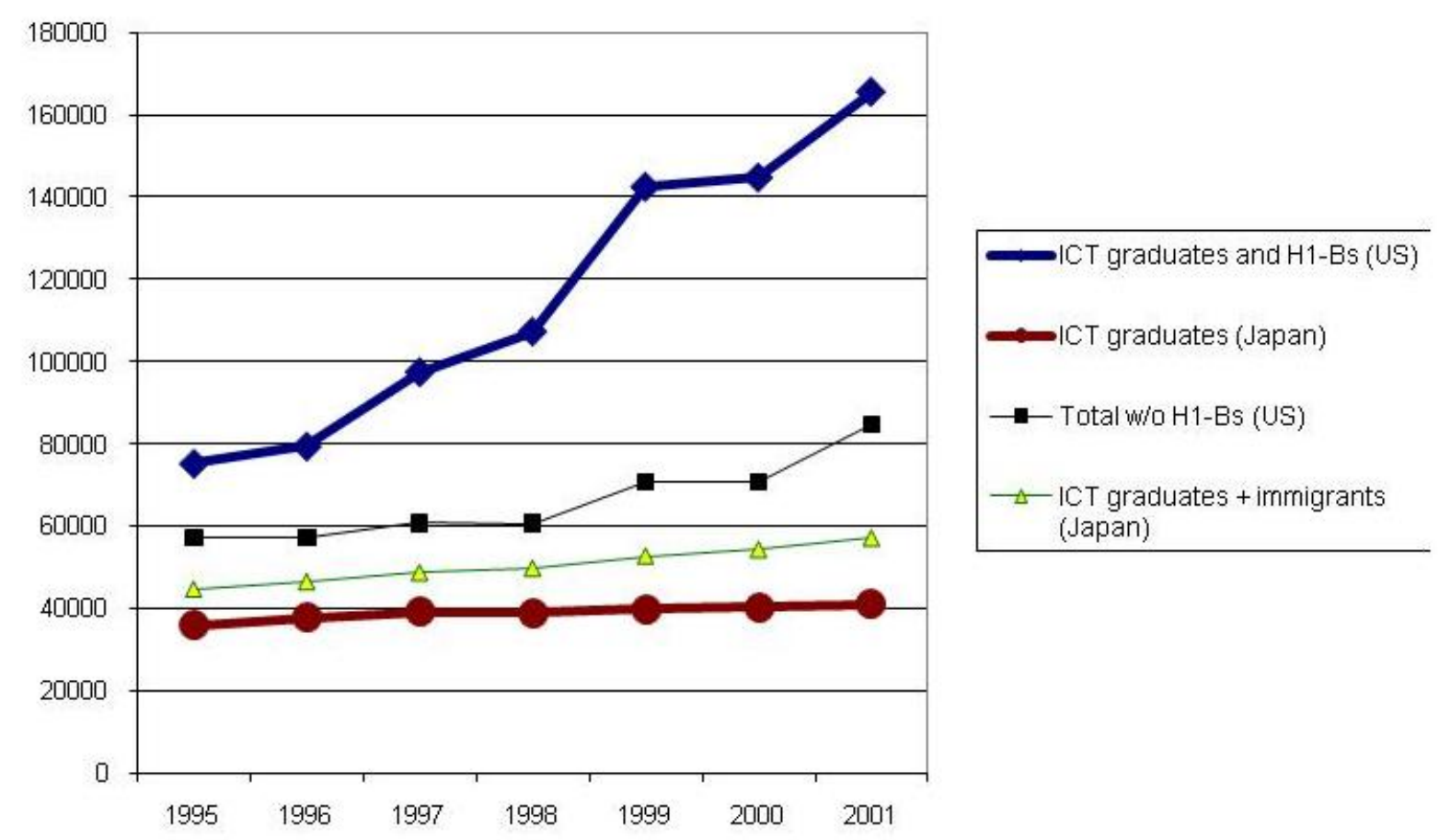

These data are obviously imperfect in many respects - only a fraction of IT graduates will enter employment in IT industries in the countries in which they study, and only a fraction of those who obtain employment in the IT industry will be engaged in research. Likewise, our estimates of H-1B temporary workers include individuals employed in IT companies as well as individuals working for banks and insurance companies, and only a fraction of the $\mathrm{H}-1 \mathrm{Bs}$ employed in IT companies are involved in research. These data track (potential) new entrants to the IT workforce, not the total stocks of workers available for employment in the sector. Despite these caveats, the picture painted by Figure 8 is quite striking. Figure 8 indicates that the estimated pool of domestic new IT labor from which the two countries we study could draw expanded at very different rates. In 1995, the inflows of new onshore IT labor in the U.S. were about $68 \%$ greater than those in Japan. By 2001, the inflows in the U.S. were nearly three times 
bigger than those in Japan, with the difference being driven largely by H-1Bs. In some of the latter years of the sample period, the U.S. was importing more IT specialists per year than it was graduating from all IT-related bachelors, masters, and doctoral programs combined.

Figure 9 US Software Outsourcing to India, 1995-2001

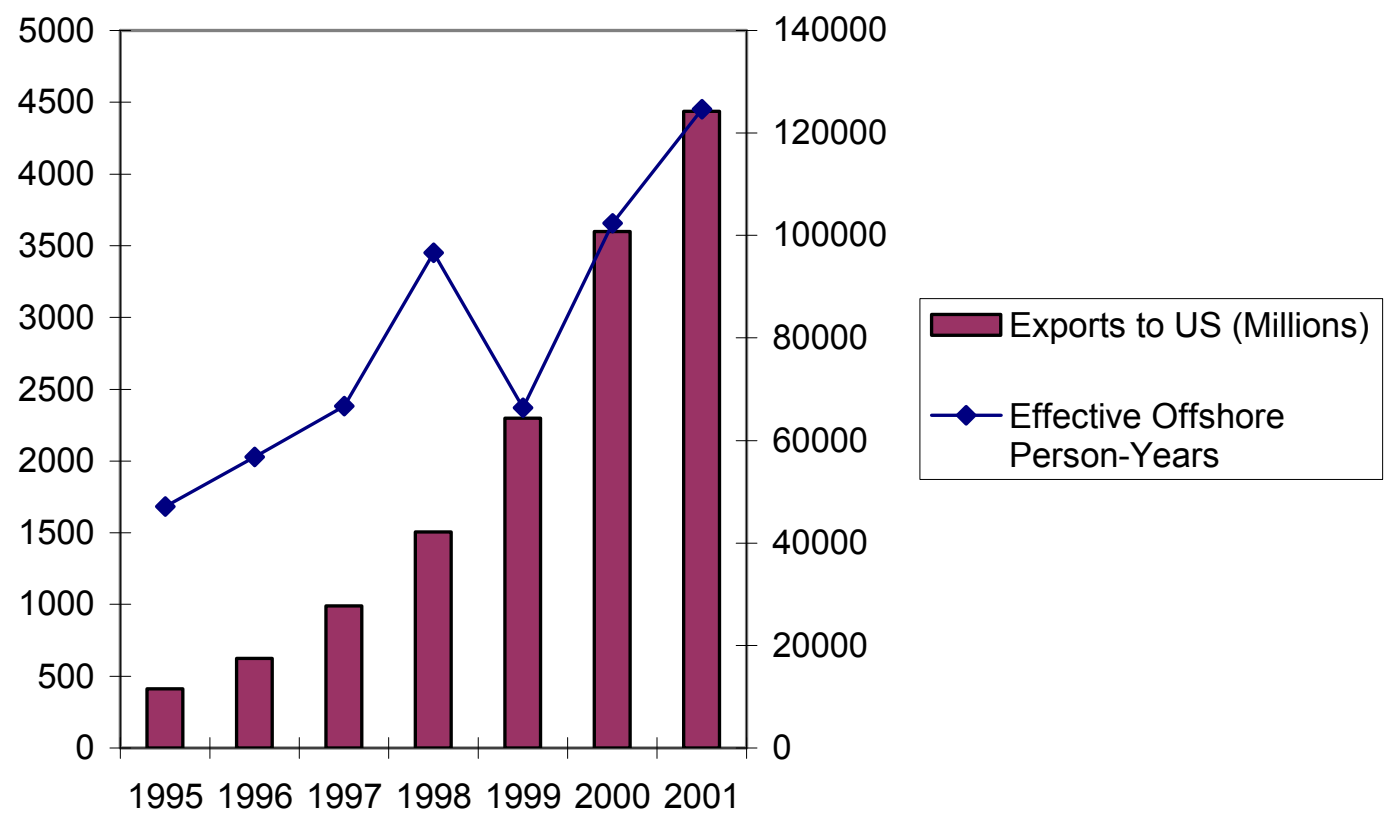

Figure 9 provides a different take on the resource constraint, by looking at offshoring of software development by the United States to India. Using data from NASSCOM on the annual levels of Indian software exports and their breakdown across regions, we compute total Indian software exports to the U.S. which is, of course, a significant underestimate of total U.S. software offshoring in all locations. Using data on average revenue per employee, we can convert these export flows into "effective offshore labor units" - this crude calculation suggests that by 2001 , more than 120,000 Indian software workers were employed full time on software 
development projects for U.S. customers. ${ }^{38}$ Similar statistics for Japanese software offshoring do not appear to exist for the late 1990s, but even by 2005 the available data suggest that Japanese firms were importing no more than 15,000 person-years and the level of imports was on the order of U.S. $\$ 1$ billon or less. ${ }^{39}$ Accounting for the level of software offshoring in the U.S. and Japan would significantly increase the resource gap implied by Figure 8 .

Given these magnitudes, it seems possible that imports of workers and, more recently, software outsourcing may have been a critical source of advantage for U.S. based firms. Relatively few of these imported experts may have been software architects of the highest order, capable of undertaking transformative innovation. However, creating, testing, and implementing software for IT product innovation required both fundamental innovators (akin to architects) and programmers undertaking more routine and standardized kinds of software engineering. America's ability to tap into an increasingly abundant (and increasingly foreign) supply of the latter may have raised the productivity of the former and enabled American firms to outproduce their rivals. It is possible to write down a simple model of IT innovation that has these features, and we include a draft version of such a model in Appendix B.

An alternative hypothesis posits that Japan's relative decline in innovative productivity was driven by lack of absorptive capacity in software (Cohen and Levinthal, 1990). Following a software-intensive technology shift, this mechanism could lead to vicious circle where the Japanese have lower absorptive capacity for software knowledge, thus produce fewer software

\footnotetext{
38 See Athreye (2005). Wages rose substantially between 1997 and 1998 - so much so that the "implied labor units" actually fell between these years. Note that NASSCOM's "export" data often include revenue derived from projects to which Indian employees working in the U.S. on H-1B visas have contributed. We have attempted to correct for this in the data.

${ }^{39}$ See Kojima and Kojima (2007). These authors also use survey data and direct interviews to analyze the reasons for relatively low levels of software offshoring. Language and cultural barriers were identified as an important constraints limiting Japanese offshoring, especially to India. Japanese offshoring has focused much more on China, which has a much smaller and less well developed software offshoring sector than India.
} 
inventions, which in turn again diminishes their absorptive capacity. ${ }^{40}$ A related strand of management literature has focused on how managerial mindsets affect the (in)ability of firms to make strategic shifts. The key assertion is that managers develop mindsets, formed through years of experience, which in turn guide their decisions. However, when the environment changes, these mindsets may prevent managers from responding to the change (Bettis and Hitt, 1995). The problem is more severe when managers have less experience in diverse settings relative to U.S. firms. The tendency of Japanese firms to practice lifetime employment and promote managers from within could exacerbate this problem.

\section{Initial Evidence for Distinguishing Between Possible Hypotheses}

The two possible explanations yield different predictions regarding what types of innovative activities Japanese firms should undertake in Japan and abroad. If they are constrained by their software knowledge pool at home, then Japanese firms will have the incentive to tap into foreign knowledge pools by setting up software intensive R\&D facilities abroad. Thus, if we observe that innovative efforts of Japanese firms are markedly more software intensive when done outside Japan, this would suggest the existence of the software knowledge/labor constraint in Japan.

What we observe is consistent with the constraint hypothesis. ${ }^{41}$ The share of software patents in total patents invented in Japan and assigned to the Japanese firms in our sample is $6 \%$. However, the share of software patents in total patents invented in the US and assigned to the Japanese firms is significantly higher $-33 \%$. Similarly, software patents represent $24 \%$ of total

\footnotetext{
40 This idea is similar to the notions of technological lock-in (Arthur, 1989) and learning myopia (Levinthal and March, 1993)

${ }^{41}$ While we do not report these results in the paper, they are available by request.
} 
patents invented in other parts of the world. This suggests Japanese firms are disproportionally likely to engage in software innovation abroad. Further US invented patents assigned to Japanese firms are more likely to cite software innovation than those invented in Japan. These patterns hold when we focus on individual sectors - electronics, semiconductors, IT hardware - but is strongest in IT hardware.

This does not rule out managerial myopia insofar as Japanese firms that recognize the importance of using software knowledge are also willing and able to invest in software related innovation activities abroad. It does imply that conducting software intensive research in Japan is more difficult than doing so elsewhere, consistent with a software resource constraint in Japan.

\section{Conclusions, Implications and Next Steps}

In this paper, we document the existence of a software-biased shift in the nature of the innovation process in information technology. Although it has been almost universally acknowledged in the computer and software engineering literature, this shift has received very little prior attention from economists or management scholars. ${ }^{42}$ This may be due, in part, to the technology- and product-specific nature of much of the evidence presented in the engineering literature. Using data on the citation patterns of all IT patents granted by the USPTO, we find evidence of a systematic shift in the nature of IT innovation that is strongly software-biased, broad-based, and very large.

We provide evidence on the economic importance of this shift by studying how it affected the innovation performance of IT firms in the United States and Japan. We show that

42 The growing literature on software patents has examined the impact of software patentability on R\&D and the impact of software patents on venture firm financing, but it has not yet addressed the impact of software technology on innovation elsewhere in IT. See Bessen and Hunt (2007), Hall and MacGarvie (2006), and Cockburn and MacGarvie (2009). 
this shift has resulted in a deterioration in the relative innovation performance of Japanese firms, and we find that this effect is more pronounced in software intensive sectors. This pattern of relative deterioration and its concentration in software-intensive sectors is robust to controls for the different levels of development of venture capital and formal mechanisms for universityindustry technology transfer in the two countries and to controls for disproportionately American ownership of key technology standards. Our findings thus provide a largely new explanation for the precipitous global decline of one of Japan's once leading industrial sectors - another development that has received relatively little attention from mainstream economists. ${ }^{43}$

Finally, we provide suggestive evidence consistent with the hypothesis that a constrained supply of software knowledge and skills in Japan could be a key factor in explaining the relatively weaker performance of Japanese IT firms in the 1990s. These findings are particularly interesting in light of a growing literature that explores linkages between factor endowments, technological change, and industry performance (e.g. Acemoglu, 2002; Dudley and Moenius, 2007). A full investigation of the connections between labor market constraints and our results is beyond the scope of the current paper, but it is a central focus of ongoing research.

Did American firms' access to a substantially larger pool of software engineering labor play an important role in their ability to outperform their Japanese rivals as the software-intensity of IT innovation rose? To the extent that the labor constraint story holds, institutional reforms in Japan that fail to open Japanese labor markets to highly skilled immigrants could leave Japanese firms at a disadvantage even in the longer run. Likewise, these results could inform the heated

\footnotetext{
43 While Japanese economists have examined the decline of Japan's electronics industries, the lack of attention from economists elsewhere is striking, particularly given the impact of the rise of Japan's electronics industry on mainstream economic thinking. This emergence, and the alleged role of subtle forms of government support in it, inspired a whole generation of mainstream trade and growth economists to experiment with models in which temporary government intervention could have lasting effects. This inspiration is evident in the work of Paul Krugman (1984), Brander and Spencer (1983), Grossman and Helpman (1991), and others.
} 
debate in the U.S. over the H-1B visa program. U.S. IT executives have long argued for

generous H-1B visa caps, maintaining that liberal immigration was key to the competitiveness of

America's IT industry. This claim deserves further scrutiny.

\section{References}

Acemoglu, D. 2002. "Technical Change, Inequality, and the Labor Market", Journal of Economic Literature, Vol. 40(1), pp.7-72.

Allan, A. et al. 2001. "2001 Roadmap for Semiconductors", Vol. 35(1), pp.42-53.

Anchordoguy, M. 2000. "Japan's Software Industry: A Failure of Institutions", Research Policy, Vol. 29, pp.391-408.

Arora, A. and Gambardella, A. 1994. "The Changing Technology of Technological Change: General and Abstract Knowledge and the Division of Innovative Labor", Research Policy, Vol. 23(5), pp.523-532.

Arora, A., Drev, M., Forman, C., and Alpman, M.D. 2007. "A Note on the Classification of Software Patents", Research Note.

Arrison, T. et al (Eds.). 1992. "Japan's Growing Technological Capability - Implications for the U.S. Economy”, Washington, D.C.: National Academy Press.

Arrison, T. and Caldwell Harris, M. 1992. "Japan's Growing Technological Capability and Implications for the U.S. Economy - An Overview", in Arrison, T. et al (Eds.), "Japan's Growing Technological Capability - Implications for the U.S. Economy", Washington, D.C.: National Academy Press.

Arthur, W.B. 1989. "Competing Technologies, Increasing Returns, and Lock-in By Historical Events", The Economic Journal, Vol. 99, pp.116-131.

Athreye, S. 2005. "The Indian Software Industry," in Arora, A. and A. Gambardella (Ed.), From Underdogs to Tigers: The Rise and Growth of the Software Industry in Brazil, China, India, Ireland, and Israel, Oxford, Oxford University Press.

Belderbos, R. 2001. "Overseas Innovation by Japanese Firms: An Analysis of Patent and Subsidiary Data. Research Policy, Vol. 30(2), pp. 313-332.

Bessen, J. and Hunt, R. 2007. "An Empirical Look at Software Patents", Journal of Economics \& Management Strategy, Vol.6(1), pp.157-189.

Bettis, R. and Hitt, M. 1993. "The New Competitive Landscape", Strategic Management Journal, Vol. 16, pp.7-19.

Bloom, N., Sadun, R., and Van Reenen, J. 2008. "Americans Do I.T. Better: US Multinationals and the Productivity Miracle", NBER Working Paper \#13085.

Brander, J. and B. Spencer, 1983. "International R\&D Rivalry and Industrial Strategy," Review of Economics and Statistics Vol. 50, pp. 707-722.

Branstetter, L. 2001. "Are Knowledge Spillovers International or Intranational in Scope?

Microeconomic Evidence from the U.S. and Japan”, Journal of International Economics, Vol. 53 , pp.53-79.

Branstetter, L. and Nakamura, Y. 2003. “Has Japan's Innovation Capacity Declined?” in Kashap, A., Blomstrom, M., Corbett, J., Hayashi, F., (Eds.), Structural Impediments to Growth in Japan, Chicago, University of Chicago Press and NBER. 
Branstetter, L. 2006. "Is Foreign Direct Investment a Channel of Knowledge Spillovers? Evidence from Japan's FDI in the U.S.," Journal of International Economics, Vol. 53, pp. 5379.

Burnham, B. 2007. “What's Next?”, Union Square Ventures Website. (http://www.unionsquareventures.com/2007/01/whats_next.html, April 21 ${ }^{\text {st }}$ 2008).

Caballero, R. and Jaffe, A. 1993. "How High are the Giants' Shoulders: An Empirical Assessment of Knowledge Spillovers and Creative Destruction in a Model of Economic Growth", NBER Macroeconomics Annual, Vol. 8, pp.15-74.

Cantwell, J. 1992. "Japan's Industrial Competitiveness and the Technological Capability of Leading Japanese Firms", in Arrison, T. et al (Eds.), "Japan's Growing Technological Capability - Implications for the U.S. Economy", Washington, D.C.: National Academy Press.

Chuma, H. and Hashimoto, N. 2007. "Moore's Law, Increasing Complexities, and the Limits of Organization: Modern Implications of the Japanese DRAM Era," working paper, Hitotsubashi University.

Cockburn, I. and M. MacGarvie. 2009. "Patents, Thickets, and the Financing of Early-Stage Firms: Evidence from the Software Industry," Journal of Economics and Management Strategy, Vol. 18(3), pp. 729-773.

Cohen, W.M. and Levinthal, D.A. 1990. "Absorptive Capacity: A New Perspective on Learning and Innovation", Administrative Science Quarterly, Vol. 35(1), pp.128-152.

Cusumano, M. 1991. “Japan's Software Factories: A Challenge to US Management”, New York, NY: Oxford University Press.

De Micheli, G. and Gupta, R.K. 1997. "Hardware/Software Co-Design", Proceedings of the IEEE, Vol. 85(3), 349-365.

Dudley, L. and Moenius, J. 2007. "The Great Realignment: How Factor-Biased Innovation Reshaped Comparative Advantage in the U.S. and Japan, 1970-1992", Japan and the World Economy, Vol. 19, pp.112-132.

"Pricing and Apps Will Drive PDA Growth", Express Computer, December $23^{\text {rd }} 2002$.

Finan, W. and Williams, C., 1992. "Implications of Japan's 'Soft Crisis': Forcing New Directions for Japanese Electronics Companies," in Arrison, T. et al (Eds.), "Japan's Growing Technological Capability - Implications for the U.S. Economy", Washington, D.C.: National Academy Press.

Fransman, M. 1995. “Japan's Computer and Communications Industry: The Evolution of Industrial Giants and Global Competitiveness", Oxford, UK: Oxford University Press.

Gore, T. 1998. "OMI - Developments in Processor Cores and Peripherals", in Roger, J.Y. (Ed). "Technologies for the Information Society: Developments and Opportunities", IOS Press.

Goto, A. 2000. "Japan's National Innovation System: Current Status and Problems," Oxford Review of Economic Policy, Vol. 16, pp. 103-113.

Goto, A. and Odagiri, H., (Eds), 2003. Science-Based Industries (in Japanese), Tokyo, NTT Publishing Co., Ltd.

Graff, B., Lormans, M., and Toetenel, H. 2003. "Embedded Software Engineering: The State of the Practice", IEEE Software, Nov/Dec Edition, pp.61-69.

Graham, S. and Mowery, D. 2003. "Intellectual Property Protection in the U.S. Software Industry" in Cohen, W. and Merrill, S.A.: Patents in the Knowledge-Based Economy.

Griliches, Z. 1981. "Market Value, R\&D, and Patents", Economic Letters, Vol. 7, pp.183-187. 
Griliches, Z. and Mairesse, J. 1984. "Productivity and R\&D at the Firm Level", in Griliches, Z. (Ed.), "R\&D, Patents, and Productivity", Chicago, IL: The University of Chicago Press and NBER.

Griliches, Z. 1990. "Patent Statistics as Economic Indicators: A Survey Part I", NBER Working Paper 3301.

Grossman, G.and E. Helpman. 1991. Innovation and Growth in the Global Economy, Cambridge, MA, MIT Press.

Hall, B. 2000. "Innovation and Market Value". In Barrell. R., Mason, G., and O’Mahoney, M. (Eds.) "Productivity, Innovation, and Economic Performance", Cambridge, UK: Cambridge University Press.

Hall, B. and Kim, D. 2000. "Valuing Intangible Assets: The Stock Market Value of R\&D Revised", University of California at Berkeley Working Paper.

Hall, B., Jaffe, A., and Trajtenberg, M. 2001. "The NBER Patent Citations Data File: Lessons, Insights, and Methodological Tools”, NBER Working Paper No. 8498.

Hall, B. and MacGarvie, M. 2006. "The Private Value of Software Patents", UC Berkeley Working Paper.

Hamada, Y. 1996. Venture Capital in Japan: Strategic Investment for the Future. (in Japanese) Tokyo, Nikkei Shimbun Press.

Hausman, J., Hall, B., and Griliches, Z. 1984. "Econometric Models for Count Data with an Application to the Patents - R\&D Relationship", NBER Technical Working Paper No. 17.

Hoshi, T., Kashyap, A., and Scharfstein, D. 1991. "Corporate Structure, Liquidity, and Investment: Evidence from Japanese Industrial Groups”, The Quarterly Journal of Economics, Vol. 106(1), pp.33-60.

Hunt, J. and Gauthier-Loiselle, M. 2008. "How Much Does Immigration Boost Innovation," NBER Working Paper no. 14312.

Jaffe, A., Trajtenberg, M., and Henderson, R. 1993. "Geographic Localization of Knowledge Spillovers as Evidenced by Patent Citations", The Quarterly Journal of Economics, Vol. 108(3), pp.577-598.

Jaffe, A. and Trajtenberg, M. 1996. "Flows of Knowledge from Universities and Federal Labs: Modeling the Flow of Patent Citations over Time and across Institutional and Geographic Boundaries", NBER Working Paper No. 5712.

Jaffe, A. and Trajtenberg, M. 2002. "Patents, Citations, and Innovations: A Window on the Knowledge Economy", Boston: MIT Press.

Japanese Ministry of Justice, Annual Report on Statistics of Legal Migrants, Various Issues.

Jorgenson, D. and Nomura, K., 2007. "The Industry Origins of the U.S.-Japan Productivity Gap," Economic Systems Research, Vol. 19(3), pp. 315-342.

Kerr, W. and Lincoln, W. 2008. "The Supply Side of Innovation: H-1B Visa Reforms and U.S. Ethnic Invention." HBS Working Paper.

Kirkegaard, J. 2005. "Outsourcing and Skill Imports: Foreign High-Skilled Workers on H-1B and L-1 Visas in the United States," Peterson Institute for International Economics Working Paper 05-15.

Kojima, S. and Kojima, M., 2007. "Making IT Offshoring Work for the Japanese Industries," in Meyer, B. and Joseph, M. (Eds.), SEAFOOD (Software Engineering for Offshore and Outsourced Development) 2007 Conference Proceedings, LNCS 4716, pp. 67-82.

Kortum, S. and Lerner, J., 2001. "Assessingthe Contribution of Venture Capital to Innovation," RAND Journal of Economics, Vol. 31(4), pp. 674-692. 
Krugman, P. 1984. "Import Protection as Export Promotion: International Competition in the Presence of Oligopoly and Economies of Scale," in Kierzkouski, H., (Ed), Monopolistic Competition in International Trade, Oxford, Oxford University Press.

Kurokawa, T., and Hayashi, S., 2008, “The ICT Human Resources as a Crisis for Japan,” (in Japanese), research draft.

Levinthal, D.A. and March, J.G. 1993. “The Myopia of Learning”, Strategic Management Journal, Vol. 14(52), pp.95-112.

Lowell, B. Lindsay. 2000. "H-1B Temporary Workers: Estimating the Population," The Center for Comparative Immigration Studies, UCSD, Working Paper 12.

Mansfield, E. 1988. "The Speed and Cost of Industrial Innovation in Japan and the United States: External vs. Internal Technology”, Management Science, Vol. 34(10), pp.1157-1168.

Ministry of Internal Affairs and Communications (MIC), Government of Japan, 2008, "Research Report on High-Level ICT Human Resource Development," (in Japanese), MIC website.

Nagaoka, S. 2007. "Assessing the R\&D Management of a Firm in Terms of Speed and Science Linkage: Evidence from the U.S. Patents," Journal of Economics, Management, and Strategy, Vol. 16(1), pp. 129-156.

Odagiri, H. and Yasuda, H. 1997. "Overseas R\&D Activities of Japanese Firms," in Goto, A. and Odagiri, H. (Eds.), Innovation in Japan, Oxford, Clarendon Press.

Pakes, A. and Griliches, Z. 1984. "Patent and R\&D at the Firm Level: A First Look", NBER Working Paper No. 561.

Perfect, S. and Wiles, K. 1994. “Alternative Constructions of Tobin’s Q: An Empirical Comparison", Journal of Empirical Finance, pp.313-341.

Tanaka, T. 2003. "The Software Industry," in Goto, A. and Odagiri, H., (Eds), Science-Based Industries (in Japanese), Tokyo, NTT Publishing Co., Ltd. 


\section{Appendix A: Regression Tables}

Table I Citation Function Results

\begin{tabular}{|c|c|c|c|c|}
\hline \multirow[b]{2}{*}{ Citing Grant Year } & \multicolumn{2}{|c|}{ Full Sample } & \multicolumn{2}{|c|}{ Citations to Software Patents Only } \\
\hline & Coefficient & Std. Error & Coefficient & Std. Error \\
\hline 1993 & $0.1364 * * *$ & 0.0432 & $0.2345 * * *$ & 0.0533 \\
\hline 1994 & $0.3248 * * *$ & 0.0500 & $0.4157 * * *$ & 0.0640 \\
\hline 1995 & $0.6339 * * *$ & 0.0609 & $0.8949 * * *$ & 0.0771 \\
\hline 1996 & $1.1426 * * *$ & 0.0769 & $1.7482 * * *$ & 0.0954 \\
\hline 1997 & $1.4741 * * *$ & 0.0942 & $2.2345 * * *$ & 0.1345 \\
\hline 1998 & $1.9031 * * *$ & 0.1123 & $2.7757 * * *$ & 0.1572 \\
\hline 1999 & $2.2265 * * *$ & 0.1372 & $3.2193 * * *$ & 0.1635 \\
\hline 2000 & $2.3847 * * *$ & 0.1622 & $3.4400 * * *$ & 0.1971 \\
\hline 2001 & $2.8789 * * *$ & 0.1978 & $3.7422 * * *$ & 0.2304 \\
\hline 2002 & $3.3690 * * *$ & . & $3.98453 * * *$ & . \\
\hline \multicolumn{5}{|l|}{ Cited Grant Year } \\
\hline 1981 & $-0.6114 * * *$ & 0.0184 & $-0.6314 * * *$ & 0.0191 \\
\hline 1982 & $-0.7758 * * *$ & 0.0119 & $-0.7851 * * *$ & 0.0127 \\
\hline$\ldots$ & $\cdots$ & .. & $\ldots$ & $\ldots$ \\
\hline 2000 & $-0.9977 * * *$ & 0.0004 & $-0.9981 * * *$ & 0.0003 \\
\hline 2001 & $-0.9988 * * *$ & 0.0005 & $-0.9990 * * *$ & 0.0005 \\
\hline Citing Patent From Japan & $-0.3358 * * *$ & 0.0220 & $-0.3916 * * *$ & 0.0231 \\
\hline $\begin{array}{l}\text { Cited Software Patent } \\
\text { Citing Patent From }\end{array}$ & $1.3483 * * *$ & 0.0484 & $\mathrm{n} / \mathrm{a}$ & $\mathrm{n} / \mathrm{a}$ \\
\hline $\begin{array}{l}\text { Japan X Cited } \\
\text { Software Patent }\end{array}$ & $-0.9225 * * *$ & 0.0590 & $\mathrm{n} / \mathrm{a}$ & $\mathrm{n} / \mathrm{a}$ \\
\hline Obsolescence & $0.3824 * * *$ & 0.0053 & $0.3978 * * *$ & 0.0062 \\
\hline Diffusion & $0.0002 * * *$ & 0.0000 & $0.0003 * * *$ & 0.0000 \\
\hline Adj R-Squared & \multicolumn{2}{|c|}{0.8526} & \multicolumn{2}{|c|}{0.6460} \\
\hline Number of Obs. & \multicolumn{2}{|c|}{804} & \multicolumn{2}{|c|}{402} \\
\hline
\end{tabular}

Table II Software Intensity by Sector, Firms in Tobin's Q Regression Sample, 1993-1999

\begin{tabular}{llllll} 
& \multicolumn{2}{c}{ Share of Software Patents } & \multicolumn{2}{c}{ Share of Citations to Software Patents } \\
\hline Industry & No. of Firms & Mean & St. Deviation & Mean & St. Deviation \\
\hline Electronics & 68 & $0.0139(* * / * *)$ & 0.0183 & $0.1650(* * / * *)$ & 0.1528 \\
Semiconductors & 56 & $0.1452(* * / * *)$ & 0.1684 & $0.2691(* * *)$ & 0.2099 \\
IT Hardware & 99 & $0.2320(* * / * *)$ & 0.2200 & $0.3316(* * / *)$ & 0.2100
\end{tabular}

** - Test for equality of means rejected at $5 \%$ level for a pair of industries, ${ }^{*}$ - Test for equality of means rejected at $10 \%$ level for a pair of industries

( / ) - First term in bracket represents the upper pair, second term in bracket represents the lower pair 
Table III Software Patent Shares by Sector and Firm Origin, Tobin's Q Regression Sample, 1983-1999

\begin{tabular}{|c|c|c|c|c|c|c|}
\hline & \multicolumn{3}{|c|}{ US Firms } & \multicolumn{3}{|c|}{ Japanese Firms } \\
\hline Industry & No. of Firms & Mean & St. Deviation & No. of Firms & Mean & St. Deviation \\
\hline Electronics & 16 & $0.0248(* * / * *)$ & 0.0261 & 52 & $0.0106(* / * *)$ & 0.0137 \\
\hline Semiconductors & 43 & $0.1820(* * / * *)$ & 0.1749 & 13 & $0.0234(* / * *)$ & 0.0450 \\
\hline IT Hardware & 76 & $0.2822(* * / * *)$ & 0.2277 & 23 & $0.0663(* * / * *)$ & 0.0387 \\
\hline
\end{tabular}

** - Test for equality of means rejected at $5 \%$ level for a pair of industries, ${ }^{*}$ - Test for equality of means rejected at $10 \%$ level for a pair of industries

( / ) - First term in bracket represents the upper pair, second term in bracket represents the lower pair

Table III-2 Share of Citations to Software by Non-Software IT Patents by Sector and Firm Origin, Tobin's Q Regression Sample, 1983-1999

\begin{tabular}{|c|c|c|c|c|c|c|}
\hline & \multicolumn{3}{|c|}{ US Firms } & \multicolumn{3}{|c|}{ Japanese Firms } \\
\hline Industry & No. of Firms & Mean & St. Deviation & No. of Firms & Mean & St. Deviation \\
\hline Electronics & 16 & $0.1160(* * / * *)$ & 0.1231 & 52 & $0.1800(/ * *)$ & 0.1589 \\
\hline Semiconductors & 43 & $0.3089(* * /)$ & 0.2118 & 13 & $0.1374(/ * *)$ & 0.1434 \\
\hline IT Hardware & 76 & $0.3378(* * /)$ & 0.2260 & 23 & $0.3109(* * / * *)$ & 0.1476 \\
\hline
\end{tabular}

** - Test for equality of means rejected at $5 \%$ level for a pair of industries, ${ }^{*}$ - Test for equality of means rejected at $10 \%$ level for a pair of industries

( / ) - First term in bracket represents the upper pair, second term in bracket represents the lower pair 
Table IV: Tobin's Q Regression Results - By Period

\begin{tabular}{|c|c|c|c|c|}
\hline \multirow[b]{2}{*}{$\ln Q$} & Entire Sample & 1983-1988 & 1989-1993 & 1994-1999 \\
\hline & NLS & NLS & NLS & NLS \\
\hline \multirow[t]{2}{*}{$\overline{\mathrm{RD} / \text { Assets }}$} & 0.1721 & -0.5772 & -0.1905 & 0.1972 \\
\hline & $(0.0489) * * *$ & $(0.0655) * * *$ & $(0.0566) * * *$ & $(0.0594) * * *$ \\
\hline \multirow[t]{2}{*}{ RD/Assets * Japan } & -0.1625 & 0.5819 & 0.2078 & -0.2099 \\
\hline & $(0.0494) * * *$ & $(0.0654) * * *$ & $(0.0611) * * *$ & $(0.0617) * * *$ \\
\hline \multirow[t]{2}{*}{ lnSales } & 0.0380 & 0.0498 & 0.0475 & 0.3236 \\
\hline & $(0.0016) * * *$ & $(0.0019) * * *$ & $(0.0027) * * *$ & $(0.0022) * * *$ \\
\hline$\overline{\mathrm{N}}$ & 2973 & 913 & 888 & 1172 \\
\hline R-squared & 0.4889 & 0.6051 & 0.5171 & 0.4925 \\
\hline
\end{tabular}

Table IV-2: Tobin's Q Regression Results - By Period - Software Intensity

\begin{tabular}{|c|c|c|c|c|}
\hline \multirow[b]{2}{*}{$\ln Q$} & Entire Sample & 1983-1988 & 1989-1993 & 1994-1999 \\
\hline & NLS & NLS & NLS & NLS \\
\hline \multirow[t]{2}{*}{$\mathrm{RD} /$ Assets } & 0.0619 & -0.3478 & -0.1834 & 0.0848 \\
\hline & $(0.0440)$ & $(0.1019) * * *$ & $(0.0689) * * *$ & $(0.0524)$ \\
\hline \multirow[t]{2}{*}{ RD/Assets * Japan } & 0.0514 & 0.3375 & 0.3289 & -0.0042 \\
\hline & $(0.0643)$ & $(0.1023) * * *$ & $(0.0934) * * *$ & $(0.0922)$ \\
\hline \multirow[t]{2}{*}{ RD/Assets * Sof.Intensity } & 0.2568 & -0.0498 & 0.3557 & 0.1671 \\
\hline & $(0.1233) * *$ & $(0.0816)$ & $(0.2259)$ & $(0.1681)$ \\
\hline $\mathrm{N}$ & 2973 & 913 & 888 & 1172 \\
\hline R-squared & 0.5108 & 0.6154 & 0.5304 & 0.4991 \\
\hline
\end{tabular}


Table V: Patent Production Function Results: Entire Sample and By Sector

\begin{tabular}{|c|c|c|c|c|c|c|c|c|c|c|c|c|}
\hline & \multicolumn{3}{|c|}{ Entire Sample } & \multicolumn{3}{|c|}{ Electronics } & \multicolumn{3}{|c|}{ Semiconductors } & \multicolumn{3}{|c|}{ IT Hardware } \\
\hline & OLS & $\mathrm{RE}$ & FE & OLS & $\mathrm{RE}$ & FE & OLS & $\mathrm{RE}$ & FE & OLS & $\mathrm{RE}$ & FE \\
\hline $\log R \& D$ & $\begin{array}{l}0.8300 \\
(0.0452)\end{array}$ & $\begin{array}{l}0.1865 \\
(0.2159)\end{array}$ & $\begin{array}{l}0.0124 \\
(0.2178)\end{array}$ & $\begin{array}{l}1.0778 \\
(0.0711)\end{array}$ & $\begin{array}{l}0.6272 \\
(0.0515)\end{array}$ & $\begin{array}{l}0.2364 \\
(0.0649)\end{array}$ & $\begin{array}{l}0.6294 \\
(0.0814)\end{array}$ & $\begin{array}{l}0.1393 \\
(0.0393)\end{array}$ & $\begin{array}{l}0.0330 \\
(0.0369)\end{array}$ & $\begin{array}{l}0.7564 \\
(0.0758)\end{array}$ & $\begin{array}{l}0.1286 \\
(0.0301)\end{array}$ & $\begin{array}{l}0.0183 \\
(0.0299)\end{array}$ \\
\hline Time 1989-1993 & $\begin{array}{l}0.5256 \\
(0.1312)\end{array}$ & $\begin{array}{l}0.5409 \\
(0.0684)\end{array}$ & $\begin{array}{l}0.5388 \\
(0.0624)\end{array}$ & $\begin{array}{l}0.0578 \\
(0.1611)\end{array}$ & $\begin{array}{l}0.1209 \\
(0.1314)\end{array}$ & $\begin{array}{l}0.1771 \\
(0.1252)\end{array}$ & $\begin{array}{l}0.4726 \\
(0.2566)\end{array}$ & $\begin{array}{l}0.6685 \\
(0.1486)\end{array}$ & $\begin{array}{l}0.7089 \\
(0.1282)\end{array}$ & $\begin{array}{l}0.6885 \\
(0.1718)\end{array}$ & $\begin{array}{l}0.6516 \\
(0.0907)\end{array}$ & $\begin{array}{l}0.6342 \\
(0.0834)\end{array}$ \\
\hline Time 1994-1999 & $\begin{array}{l}1.0674 \\
(0.1704)\end{array}$ & $\begin{array}{l}1.3098 \\
(0.0665)\end{array}$ & $\begin{array}{l}1.3752 \\
(0.0612)\end{array}$ & $\begin{array}{l}-0.3737 \\
(0.2574)\end{array}$ & $\begin{array}{l}-0.2725 \\
(0.1305)\end{array}$ & $\begin{array}{l}-0.1716 \\
(0.1249)\end{array}$ & $\begin{array}{l}1.3183 \\
(0.3015)\end{array}$ & $\begin{array}{l}1.9250 \\
(0.1422)\end{array}$ & $\begin{array}{l}2.1288 \\
(0.1241)\end{array}$ & $\begin{array}{l}1.2491 \\
(0.2083)\end{array}$ & $\begin{array}{l}1.3759 \\
(0.0883)\end{array}$ & $\begin{array}{l}1.4005 \\
(0.0819)\end{array}$ \\
\hline Japan Dummy & $\begin{array}{l}0.4003 \\
(0.1974)\end{array}$ & $\begin{array}{l}0.4853 \\
(0.1814)\end{array}$ & n.a. & $\begin{array}{l}-0.5425 \\
(0.2600)\end{array}$ & $\begin{array}{l}-1.2094 \\
(0.2796)\end{array}$ & n.a. & $\begin{array}{l}0.2269 \\
(0.3511)\end{array}$ & $\begin{array}{l}0.3428 \\
(0.3336)\end{array}$ & n.a. & $\begin{array}{l}0.9121 \\
(0.3239)\end{array}$ & $\begin{array}{l}1.7556 \\
(0.2869)\end{array}$ & n.a. \\
\hline Japan * Time 1989-1993 & $\begin{array}{l}-0.6963 \\
(0.1515)\end{array}$ & $\begin{array}{l}-0.2654 \\
(0.0943)\end{array}$ & $\begin{array}{l}-0.1614 \\
(0.0861)\end{array}$ & $\begin{array}{l}-0.3780 \\
(0.1941)\end{array}$ & $\begin{array}{l}-0.1123 \\
(0.1479)\end{array}$ & $\begin{array}{l}0.0072 \\
(0.1415)\end{array}$ & $\begin{array}{l}-0.2529 \\
(0.3583)\end{array}$ & $\begin{array}{l}-1.0391 \\
(0.2621)\end{array}$ & $\begin{array}{l}-0.0492 \\
(0.2264)\end{array}$ & $\begin{array}{l}-0.7936 \\
(0.2038)\end{array}$ & $\begin{array}{l}-0.2734 \\
(0.1472)\end{array}$ & $\begin{array}{l}-0.1812 \\
(0.1353)\end{array}$ \\
\hline Japan * Time 1994-1999 & $\begin{array}{l}-1.0023 \\
(0.2003)\end{array}$ & $\begin{array}{l}-0.7146 \\
(0.0946)\end{array}$ & $\begin{array}{l}-0.6435 \\
(0.0869)\end{array}$ & $\begin{array}{l}0.2891 \\
(0.2884)\end{array}$ & $\begin{array}{l}0.5941 \\
(0.1490)\end{array}$ & $\begin{array}{l}0.7105 \\
(0.1431)\end{array}$ & $\begin{array}{l}-1.1184 \\
(0.5263)\end{array}$ & $\begin{array}{l}-1.1435 \\
(0.2498)\end{array}$ & $\begin{array}{l}-1.1602 \\
(0.2173)\end{array}$ & $\begin{array}{l}-1.0569 \\
(0.2767)\end{array}$ & $\begin{array}{l}-0.7088 \\
(0.1491)\end{array}$ & $\begin{array}{l}-0.6333 \\
(0.1377)\end{array}$ \\
\hline Electronics & $\begin{array}{l}-0.9619 \\
(0.2402)\end{array}$ & $\begin{array}{l}0.8915 \\
(0.2064)\end{array}$ & n.a. & & & & & & & & & \\
\hline Semiconductors & $\begin{array}{l}-1.1759 \\
(0.2258)\end{array}$ & $\begin{array}{l}0.6300 \\
(0.2145)\end{array}$ & n.a. & & & & & & & & & \\
\hline IT Hardware & $\begin{array}{l}-1.1356 \\
(0.2443)\end{array}$ & $\begin{array}{l}0.5599 \\
(0.1938)\end{array}$ & n.a. & & & & & & & & & \\
\hline _cons & n.a. & n.a. & $\begin{array}{l}2.5148 \\
(0.0972)\end{array}$ & $\begin{array}{l}-0.9807 \\
(0.3612)\end{array}$ & $\begin{array}{l}0.9164 \\
(0.3284)\end{array}$ & $\begin{array}{l}1.5926 \\
(0.2433)\end{array}$ & $\begin{array}{l}-0.4581 \\
(0.2985)\end{array}$ & $\begin{array}{l}0.5473 \\
(0.2386)\end{array}$ & $\begin{array}{l}1.7714 \\
(0.1657)\end{array}$ & $\begin{array}{l}-1.0538 \\
(0.3462)\end{array}$ & $\begin{array}{l}1.0991 \\
(0.1978)\end{array}$ & $\begin{array}{l}2.9155 \\
(0.1540)\end{array}$ \\
\hline
\end{tabular}


Table VI: Tobin's Q Regressions - US and Japan - Comparing Time Trends

\begin{tabular}{|c|c|c|c|c|c|c|c|c|c|}
\hline \multirow[b]{2}{*}{$\ln Q$} & \multicolumn{3}{|c|}{ Entire Sample } & \multicolumn{4}{|l|}{ US } & \multicolumn{2}{|l|}{ Japan } \\
\hline & $\mathrm{FE}$ & NLS & & $\mathrm{FE}$ & & NLS & & $\mathrm{FE}$ & NLS \\
\hline \multirow[t]{2}{*}{$\mathrm{RD} /$ Assets } & 0.0175 & 0.1242 & & -1.2380 & & -0.1531 & & 0.0072 & 0.0105 \\
\hline & $(0.0094)$ & * $\quad(0.0322)$ & $* * *$ & $(0.1771)$ & $* * *$ & $(0.1791)$ & & $(0.0087)$ & $(0.0071)$ \\
\hline \multirow[t]{2}{*}{ RD/Assets * Year_1989-1993 } & 0.0084 & -0.0629 & & -0.3799 & & -0.4052 & & 0.0059 & 0.0072 \\
\hline & $(0.0246)$ & $(0.0385)$ & $*$ & $(0.0920)$ & $* * *$ & $(0.0711)$ & $* * *$ & $(0.0234)$ & $(0.0306)$ \\
\hline \multirow[t]{2}{*}{ RD/Assets * Year_1994-1999 } & 0.01256 & -0.0726 & & 1.2647 & & 0.2194 & & -0.0026 & -0.0008 \\
\hline & $(0.0111)$ & $(0.0428)$ & $*$ & $(0.1771)$ & $* * *$ & $(0.1838)$ & & $(0.0275)$ & $(0.0250)$ \\
\hline $\mathrm{N}$ & 2973 & 2973 & & 1529 & & 1529 & & 1444 & 1444 \\
\hline R-squared & 0.1129 & 0.5180 & & 0.2207 & & 0.5883 & & 0.2888 & 0.7532 \\
\hline
\end{tabular}

Firm size coefficient, Industry controls, and other controls not reported

Table VII: Total Sample Period Tobin's Q Regression - Logarithmic Approximation FE and NLS - US and Japanese Firms - Electronics

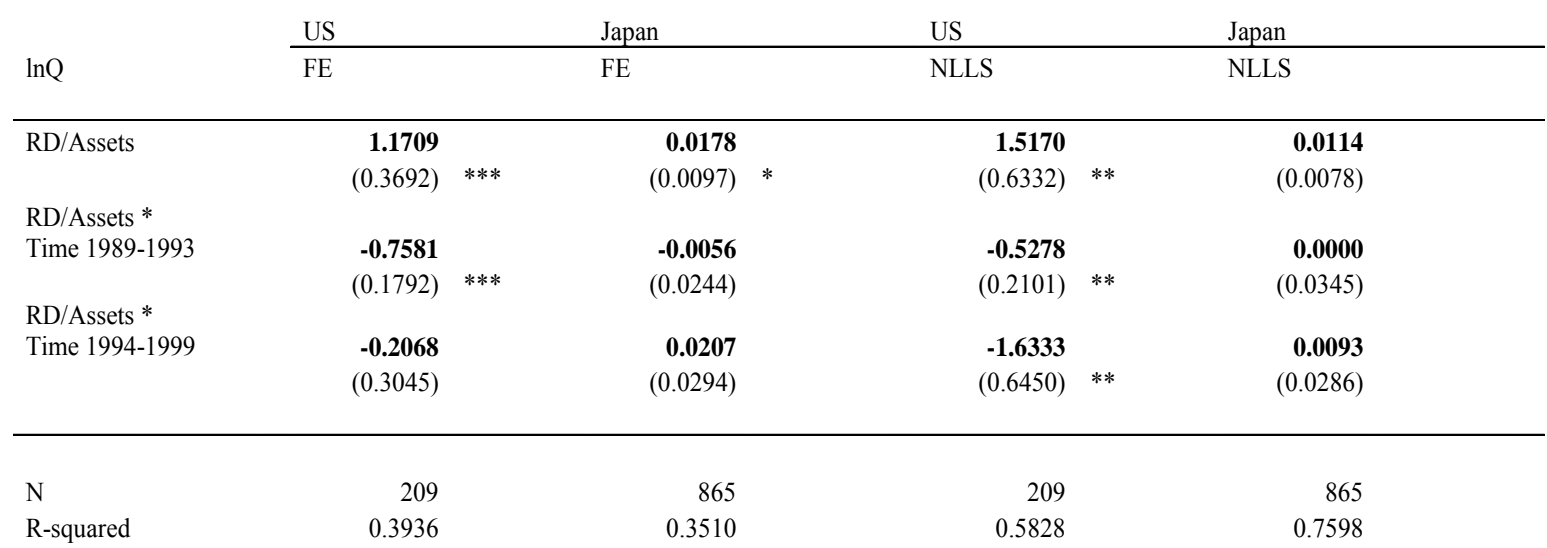

Firm size, time dummies, and other controls not reported 
Table VIII: Total Sample Period Tobin's Q Regression - Logarithmic Approximation FE and NLS - US and Japanese Firms - Semiconductors

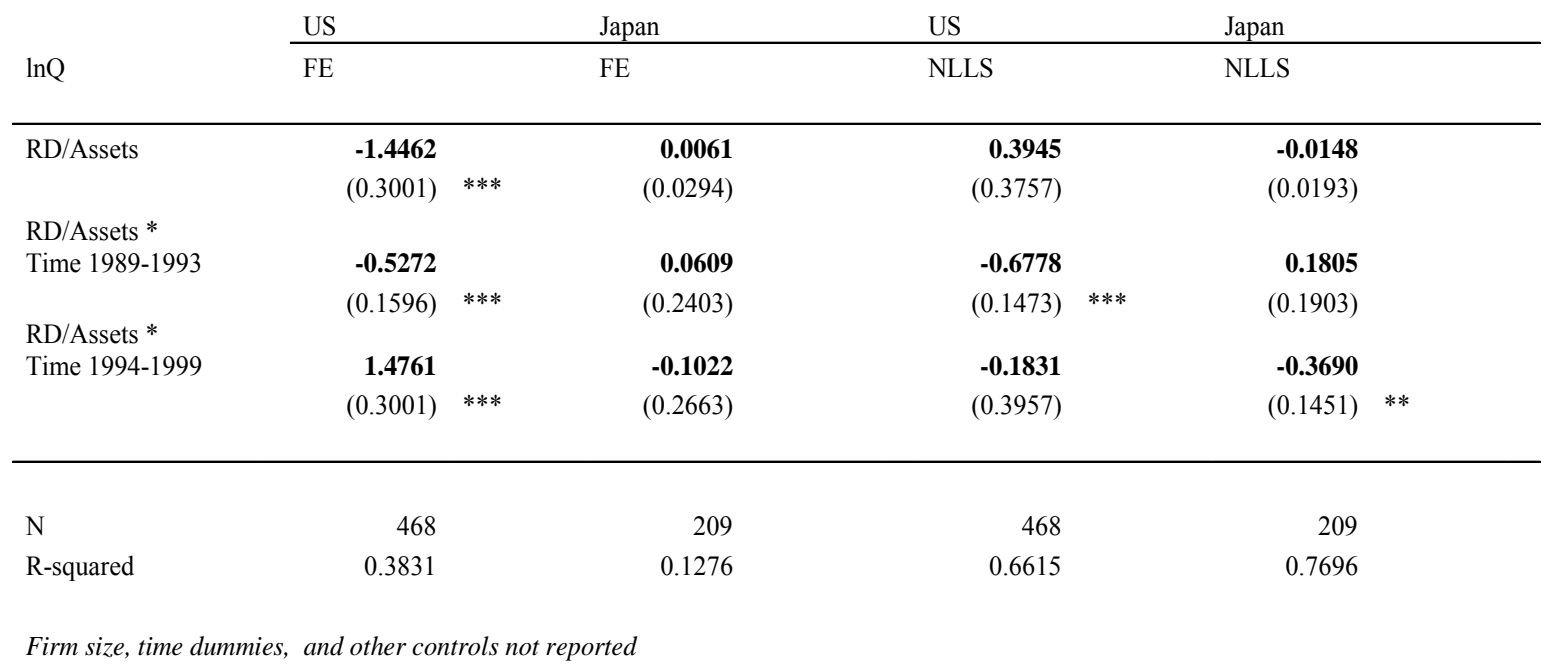

Table IX Total Sample Period Tobin's Q Regression - Logarithmic Approximation FE and NLS - US and Japanese Firms - IT Hardware

\begin{tabular}{|c|c|c|c|c|c|c|c|}
\hline \multirow[b]{2}{*}{$\ln Q$} & \multicolumn{2}{|l|}{ US } & Japan & \multicolumn{2}{|l|}{ US } & \multicolumn{2}{|l|}{ Japan } \\
\hline & FE & & $\mathrm{FE}$ & NLLS & & NLLS & \\
\hline \multirow[t]{2}{*}{$\mathrm{RD} /$ Assets } & -1.6589 & & -0.0742 & 0.6943 & & 0.2306 & \\
\hline & $(0.2633)$ & $* * *$ & $(0.1185)$ & $(0.3546)$ & $* *$ & $(0.1253)$ & * \\
\hline \multicolumn{8}{|l|}{$\mathrm{RD} /$ Assets * } \\
\hline \multirow[t]{2}{*}{ Time 1989-1993 } & 0.2243 & & -0.1399 & 0.2566 & & -0.1201 & \\
\hline & $(0.1553)$ & & $(0.1475)$ & $(0.0946)$ & $* * *$ & $(0.1761)$ & \\
\hline \multicolumn{8}{|l|}{$\mathrm{RD} /$ Assets * } \\
\hline \multirow{2}{*}{ Time 1994-1999 } & 1.0624 & & -0.0154 & 1.2291 & & -0.1962 & \\
\hline & $(0.2725)$ & $* * *$ & $(0.1469)$ & $(0.3558)$ & $* * *$ & $(0.1754)$ & \\
\hline $\mathrm{N}$ & 852 & & 370 & 852 & & 370 & \\
\hline R-squared & 0.1798 & & 0.2604 & 0.5607 & & 0.7524 & \\
\hline
\end{tabular}




\section{Appendix B}

\section{A Simple Model of Skill Complementarity in IT Innovation}

In this section we present a very simple model of IT innovation in which we embed a particular kind of skill complementarity. To create new IT innovations (Q), firms most employ hardware engineers $(\mathrm{H})$ and software engineers $(\mathrm{S})$. The highly labor intensive nature of software development requires contributions from very highly-skilled software "architects" $\left(S_{H}\right)$ and less-skilled software workers "code warriors" $\left(S_{L}\right)$, who actually create, test, and maintain the subroutines and program modules scripted out by the architects. These two kinds of software engineers are complements. The productivity of the highly skilled architects, $S_{H}$, is enhanced by hiring large numbers of code warriors and vice versa. To build this complementarity into our innovation production function in a simple way, we set out a stylized model that closely follows Bloom, Sadun, and Van Reenen (2008). Our notation and our exposition borrow heavily from this earlier work. A key idea in all that follows, though, is that U.S. firms have access to a much larger pool of "code warriors," which confers on them an advantage that rises in importance if and when innovation in IT becomes more software intensive.

$$
Q_{i t}=A_{i t} S_{L i t}^{\alpha^{S_{L}}} S_{H i t}^{\alpha^{S_{H}}+\sigma_{L}} H_{i t}^{\alpha^{H}-\sigma_{L}}
$$

Firms produce research output $(Q)$ by combining hardware engineers $(H)$, software architects $\left(S_{H}\right)$ and code warriors $\left(S_{L}\right)$; for now, all other inputs (lab equipment, materials) are assumed to be zero for simplicity. In the exposition that follows, time and firm subscripts will be suppressed for notational simplicity. Equation B-1 captures the notion that the two types of software engineers are complements when $\sigma>0$. This implies that the software architect per hardware engineer ratio is increasing in the level of code warriors. 
We can think of (B-1) as a revenue function with monopolistic competition and isoelastic demand so $\alpha^{S_{L}}+\alpha^{S_{H}}+\alpha^{H}<1$. Note that it is not necessarily the case that $\alpha^{S_{L}}>0$. In some segments of IT, larger numbers of code warriors may not be beneficial for output $\left(\alpha^{S_{L}}=0\right)$. Since this is a nonstandard revenue/production function, we need to ensure that it is concave by assuming that

$0 \leq \alpha^{H}-S_{L} \leq 1$

and

$0 \leq \alpha^{S_{H}}+\sigma S_{L} \leq 1$

Let us consider the case in which $S_{L}$ is fixed in the short run, because immigration quotas for H1Bs are binding or because establishing a relationship with an Indian offshore programming company takes time. Let's abstract from the details of production and assume that the flow profits from innovation are:

$\Pi=Q-W H-\rho^{S_{H}} S_{H}-\rho^{S_{L}} S_{L}$

Where $\mathrm{W}$ is the wage rate of hardware engineers, $\rho^{S_{H}}$ is the wage rate of software architects, and $\rho^{S_{L}}$ is the wage rate of code warriors. The first order conditions for software architects and hardware engineers will be:

$$
\begin{aligned}
& \alpha^{S_{H}} \frac{Q}{S_{H}}+\sigma \frac{S_{L} Q}{S_{H}}=\rho^{S_{H}} \\
& \alpha^{H} \frac{Q}{H}-\sigma \frac{S_{L} Q}{H}=W
\end{aligned}
$$

Combining these first order conditions gives us

$$
\ln \left(\frac{S_{H}}{H}\right)=\ln \left(\frac{W}{\rho^{S_{H}}}\right)+\ln \left(\frac{\alpha^{S_{H}}+\sigma_{L}}{\alpha^{H}-\sigma_{L}}\right)
$$


Consequently, the intensity of use of software architects relative to hardware engineers is going to be increasing in the stock of code warriors:

$$
\frac{\partial \ln \left(S_{H} / H\right)}{\partial S_{L}}=\left(\frac{\sigma}{\alpha^{S_{H}}+\sigma_{L}}\right)+\left(\frac{\sigma}{\alpha^{H}-\sigma S_{L}}\right)>0
$$

These equations give us a number of useful results. First, an increase in the stock of code warriors directly raises innovative output (see B-1). Second, an increase in the stock of code warriors raises the marginal product of software architects (B-5). Third, an increase in the stock of code warriors raises the intensity of use of software architects relative to hardware engineers. Fourth, let's assume that there is software architect biased technological change in IT, such that $\alpha^{S_{H}}$ increases for all firms, as firms can increasingly utilize software to produce increases in product functionality that would have required hardware-based innovation in the past. This would lead all firms to become more software intensive in terms of their technological trajectory, but the complementarity between code warriors and software architects means that firms (and countries) with more code warriors will become even more intensive in their use of software architects, because the rising output elasticity of software architects is further reinforced by the presence of code warriors. This is consistent with the outcome that firms with more code warriors will be disproportionately more successful in sectors where the use of software architects is more intensive, while they will be relatively less successful in sectors where software architects are less important. Finally, a large stock of code warriors would not lower the price (wage) of software architects. Rather, by raising the marginal product of software architects, it would actually be consistent with wages for software architects that were higher than those in a code warrior starved country.

The implications of this assumed complementarity are not substantially altered when we allow the stock of code warriors to be fully flexible in the long run. Following Bloom, Sadun, 
and Van Reenen, it can be shown that if the price of code warriors is lower in the US than in Japan, then $S_{L}{ }^{* U S}$ is greater than $S_{L}{ }^{\text {Japan }}$. It can also be shown that an increase in the output elasticity of software architects leads to an increase in their use - in other words, a change in the technology of technological change that favors software will lead to a greater use of software architects. Finally, it can be shown that a decrease in the price of code warriors raises the optimal employment of software architects.

It is harder to get a model like this one to directly produce the result that research productivity per unit of expenditure will go up when the price of code warriors goes down. Because there are no costs of adjustment, when the output elasticity of a particular factor rises, more of that factor is hired (instantly) until the marginal unit of factor employed is generating an amount of output just equal in value to the cost of employing that factor. However, if there are significant adjustment costs in both code warrior and software architect labor forces, then this adjustment process will take time - possibly years. So, in the transition to the new steady state, US firms (with initially higher stocks of code warriors) could realize at least a temporary boost to research productivity. This advantage could show up in both patents per R\&D dollar and in market value based measures of IT investment. In a model that is mathematically similar to this one, Bloom, Sadun, and Van Reenen show that bringing quadratic costs of adjustment of software architect and code warrior labor forces into the model can generate these kinds of productivity growth differences.

In any case, this simple model helps illustrate the complementarity we think has been at work in (re)shaping the global competitive landscape within the IT sector. IT innovation became more software intensive. The optimal response for all IT firms was to respond by hiring more software engineers relative to hardware engineers. In the U.S., the effective endowment of code- 
warriors was quite high, and this made high-skilled software engineers even more valuable and more effective in terms of enhancing innovative output. In Japan, the availability of code warriors was strictly limited. The corresponding limited availability (and relatively high price) of the lower-skilled software workers lowered the marginal product of higher-skilled software workers, from the perspective of Japanese firms. In the presence of the labor constraint they faced, the optimal response of Japanese firms was to invest in relatively fewer software engineers (at all skill levels) than their U.S. counterparts. This, however, limited their innovative output relative to their U.S. counterparts and helped bring about the decline in relative performance documented in this paper. 